\title{
Monsoonal response to mid-holocene orbital forcing in a high resolution GCM
}

\author{
J. H. C. Bosmans ${ }^{1,2}$, S. S. Drijfhout ${ }^{2}$, E. Tuenter ${ }^{1,2}$, L. J. Lourens ${ }^{1}$, F. J. Hilgen ${ }^{1}$, and S. L. Weber ${ }^{1,2, \dagger}$ \\ ${ }^{1}$ Utrecht University, Faculty of Geosciences, Utrecht, The Netherlands \\ ${ }^{2}$ Royal Netherlands Meteorological Institute, KNMI, De Bilt, The Netherlands \\ $\dagger$ deceased
}

Correspondence to: J. H. C. Bosmans (j.h.c.bosmans@uu.nl)

Received: 7 October 2011 - Published in Clim. Past Discuss.: 24 October 2011

Revised: 16 February 2012 - Accepted: 17 February 2012 - Published: 3 April 2012

\begin{abstract}
In this study, we use a sophisticated highresolution atmosphere-ocean coupled climate model, ECEarth, to investigate the effect of Mid-Holocene orbital forcing on summer monsoons on both hemispheres. During the Mid-Holocene (6 ka), there was more summer insolation on the Northern Hemisphere than today, which intensified the meridional temperature and pressure gradients. Over North Africa, monsoonal precipitation is intensified through increased landward monsoon winds and moisture advection as well as decreased moisture convergence over the oceans and more convergence over land compared to the pre-industrial simulation. Precipitation also extends further north as the ITCZ shifts northward in response to the stronger poleward gradient of insolation. This increase and poleward extent is stronger than in most previous ocean-atmosphere GCM simulations. In north-westernmost Africa, precipitation extends up to $35^{\circ} \mathrm{N}$. Over tropical Africa, internal feedbacks completely overcome the direct warming effect of increased insolation. We also find a weakened African Easterly Jet. Over Asia, monsoonal precipitation during the Mid-Holocene is increased as well, but the response is different than over North-Africa. There is more convection over land at the expense of convection over the ocean, but precipitation does not extend further northward, monsoon winds over the ocean are weaker and the surrounding ocean does not provide more moisture. On the Southern Hemisphere, summer insolation and the poleward insolation gradient were weaker during the Mid-Holocene, resulting in a reduced South American monsoon through decreased monsoon winds and less convection, as well as an equatorward shift in the ITCZ. This study corroborates the findings of paleodata research as well as previous model studies, while giving a more detailed account of Mid-Holocene monsoons.
\end{abstract}

\section{Introduction}

Monsoon systems play a key role in the climate of the tropics and subtropics. Generated by the asymmetric heating of continents and oceans, they are characterised by seasonal reversals in atmospheric circulation and associated precipitation (Hastenrath, 1991; Webster, 1987a; Webster et al., 1998). The strength of monsoons varies on inter-seasonal to inter-decadal timescales, through interactions with different components of the climate system (e.g., Webster, 1987b; Shukla, 1987). Even larger changes occur on time scales of (tens of) thousands of years, when variations in the Earth's orbit induce fluctuations in the distribution of incoming solar radiation on Earth (Berger, 1978). On these orbital time scales, monsoons are primarily controlled by precession, which modifies the seasonality of insolation and, thereby, changes the asymmetric heating of continents and oceans (Ruddiman, 2007).

During the Mid-Holocene, $6000 \mathrm{yr}$ ago (6 ka), the Earth's orbit was different than today. Compared to the present-day orbital configuration, the Mid-Holocene was characterised by relatively strong insolation during boreal summer and autumn, and relatively weak insolation during austral summer and autumn (see Sect. 2.2). There is ample evidence from paleodata that the enhanced seasonal cycle of insolation on the Northern Hemisphere coincided with intensified monsoonal summer precipitation, while the reduced seasonal cycle on the Southern Hemisphere corresponded to weaker monsoons. Pollen- and plant macrofossil-based reconstructions of the $6 \mathrm{ka}$ vegetation distribution in NorthAfrica show that steppe extended up to $23^{\circ} \mathrm{N}$ in the $\mathrm{Sa}-$ hara, compared to roughly $16^{\circ} \mathrm{N}$ today, and that lake levels were higher than they are today (e.g. Street-Perrott and Perrot, 1993; Jolly et al., 1998; Kohfeld and Harrison, 2000), 
indicating increased monsoonal precipitation. Similar paleodata from Asia show that the Indian and East-Asian summer monsoons were enhanced as well (Winkler and Wang, 1993; Yu and Harrison, 1996; Yu et al., 1998). For the Southern Hemisphere, less paleodata are available, but it has been shown from pollen-based biome reconstructions and lake levels that over South America moisture levels were lower at $6 \mathrm{ka}$ (Markgraf, 1993; Baker et al., 2001; Marchant et al., 2009).

The relation between monsoon strength and orbitallyforced changes in insolation was already investigated in some of the earliest paleoclimate model studies (e.g. Kutzbach and Otto-Bliesner, 1982; Kutzbach and Guetter, 1986). These atmosphere-only experiments mostly focused on the Northern Hemisphere, showing that monsoons were enhanced during the Early- and Mid-Holocene in response to relatively strong summer insolation. By adding ocean models and/or dynamic vegetation models, several complex feedbacks that play a role in the climate's response to the initial orbital forcing have been identified (e.g. Kutzbach et al., 1996; Liu et al., 2004; Zhao et al., 2005; Ohgaito and Abe-Ouchi, 2007; Marzin and Braconnot, 2009b; Dallmeyer et al., 2010; Zhao and Harrison, 2011). Many of these modelling studies have been performed within the framework of PMIP, the Paleoclimate Modelling Intercomparison Project (Joussaume et al., 1999; Braconnot et al., 2000). In the first phase of PMIP, atmospheric general circulation models (GCMs) were used to simulate Mid-Holocene climate, applying 6 ka orbital forcing and pre-industrial greenhouse gas concentrations while keeping all other boundary conditions (sea surface temperatures, ice sheets, vegetation and land surface properties) constant at present-day values. Phase 2 of PMIP included dynamic ocean models, and for some models interactive vegetation as well (Braconnot et al., 2007a,b). The EC-Earth experiments discussed in this study are a contribution to the third phase, PMIP3, in which improved and higher-resolution models are used to further investigate the effect of Mid-Holocene orbital forcing and internal climate feedbacks.

The earlier model studies mentioned above have shown that on the Northern Hemisphere (NH) the increased summer insolation during the Mid-Holocene enhances the thermal low over the continents, which strengthens the land-sea pressure gradients, thereby reinforcing monsoon winds and bringing more moisture landward. This results in an intensified monsoon circulation and, over North-Africa, a poleward shift in precipitation. The opposite occurs on the Southern Hemisphere (SH), resulting in weaker monsoons.

Although the mechanisms of monsoon intensification/weakening are generally agreed upon, several questions remain. Some of these questions concern the spatial pattern of climate response to the orbital forcing, as paleoclimate models generally have a coarse resolution and paleodata is sparse. Another important question is what mechanism causes the northward extension of precipitation over North Africa, which is evident from paleodata, but which models fail to reproduce (Joussaume et al., 1999), even if ocean and vegetation feedbacks are included (Braconnot et al., 2007a). Besides coarse resolution, this discrepancy could also be attributed to models' sensitivity to the parameterization of clouds, atmospheric dynamics, the hydrological cycle and land-surface interactions. Several studies have shown that monsoons are better resolved when the resolution, and consequently the representation of topography, is increased (Sperber et al., 1994; Zhou and Li, 2002; Kobayashi and Sugi, 2004; Gao et al., 2006), while results remain susceptible to changes in model's parameterization (Lal et al., 1997; Masson and Joussaume, 1997; Bonfils et al., 2001; Vamborg et al., 2011).

To re-examine the monsoonal response to Mid-Holocene orbital forcing using a state-of-the-art modelling tool, we present results of a Mid-Holocene experiment with the ECEarth climate model (Hazeleger et al., 2010, 2011). ECEarth is an atmosphere-ocean coupled model with a high resolution (T159) compared with PMIP2 and PMIP3 models. EC-Earth has sophisticated parameterizations of smallscale atmospheric, hydrological and surface processes which have been tested extensively in operational weather forecasts. We believe that the high resolution and reliable, sophisticated parameterizations will yield a more detailed representation of monsoons and related circulation systems such as the Inter Tropical Convergence Zone (ITCZ). We are particularly interested in the spatial distribution of MidHolocene monsoonal precipitation and the atmospheric dynamics that explain these precipitation patterns. Many studies have described changes in precipitation (summarised in Liu et al., 2004; Braconnot et al., 2007a), but only few studies have looked into the atmospheric dynamics that cause these changes (Texier et al., 2000; Su and Neelin, 2005; Patricola and Cook, 2007; Marzin and Braconnot, 2009a).

This paper is organised as follows: Sect. 2 describes the EC-Earth model and the experimental set-up. Changes in monsoonal precipitation and the associated atmospheric dynamics (temperature and pressure gradients, wind fields, moisture advection and vertical velocity) are examined in Sect. 3. We focus on three monsoon regions: North-Africa, Asia (India and South-East Asia) and South-America. Section 4 provides a discussion of the EC-Earth Mid-Holocene experiment and a comparison to previous modelling results and paleodata studies. A conclusion is given in Sect. 5.

\section{Model and experiment set-up}

\subsection{The model: EC-Earth and pre-industrial results}

EC-Earth is a fully coupled ocean-atmosphere GCM (Global Climate Model). It is used for exploratory studies of feedbacks in the climate system as well as for future climate projections as part of CMIP5 (Hazeleger et al., 2010, 2011). The atmospheric part is based on the Integrated Forecasting 


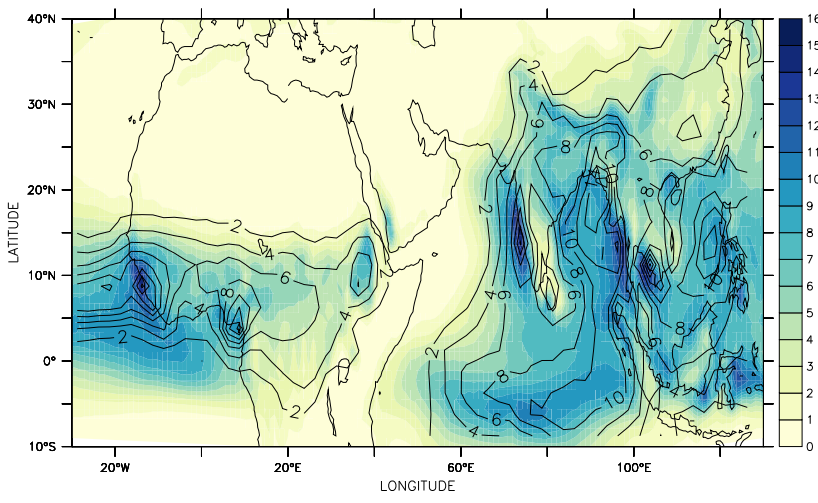

Fig. 1. JAS precipitation $\left(\mathrm{mm} \mathrm{day}^{-1}\right)$ from the EC-Earth preindustrial experiment (colour) and the CPC Merged Analyses of Precipitation dataset (contours, Xie and Arkin, 1997).

System (IFS), cycle 31R1, of the European Centre for Medium-range Weather Forecast (ECMWF). It runs at T159 horizontal resolution (roughly $1.125^{\circ} \times 1.125^{\circ}$ ) with 62 vertical levels. IFS has a new convection scheme (Bechtold et al., 2008) and the new land surface scheme H-TESSEL, which includes surface runoff (Balsamo et al., 2009). The ocean component is the NEMO model, version 2, which runs at a horizontal resolution of nominally $1^{\circ}$ with 42 vertical levels and incorporates the sea-ice model LIM2 (Madec, 2008; Sterl et al., 2011). The ocean/ice and atmosphere are coupled through the OASIS3 coupler (Valcke, 2006). The resolution of the ocean in EC-Earth is comparable to PMIP2 and PMIP3 models, but the resolution of the atmospheric component is higher than all PMIP2 models (at most $2.8^{\circ} \times 2.8^{\circ}$, Braconnot et al., 2007a) and is amongst the highest of PMIP3 models (only two of which run at a comparable resolution, see http://pmip3.lsce.ipsl.fr).

Hazeleger et al. (2010) demonstrate that EC-Earth performs well compared to CMIP3 models (see their Fig. 2). The model also captures inter-annual variability very well, as shown by the spatial and temporal variability of the modelled El Niño Southern Oscillation (see Hazeleger et al., 2010, Fig. 3). More importantly, monsoons are represented well in EC-Earth, both temporally and spatially. Figure 1 shows that EC-Earth captures the spatial pattern of JulyAugust-September precipitation over Africa and Asia very well. Furthermore, a comparison between EC-Earth, CMAP and PMIP2 models, presented in Fig. 2, illustrates that the temporal patterns of monsoon precipitation is also resolved well in EC-Earth.

\subsection{Experimental set-up: insolation forcing and boundary conditions}

Here we study two time-slice experiments performed with EC-Earth: a pre-industrial and a Mid-Holocene experiment, both at the T159L62 resolution (in the atmosphere). We use

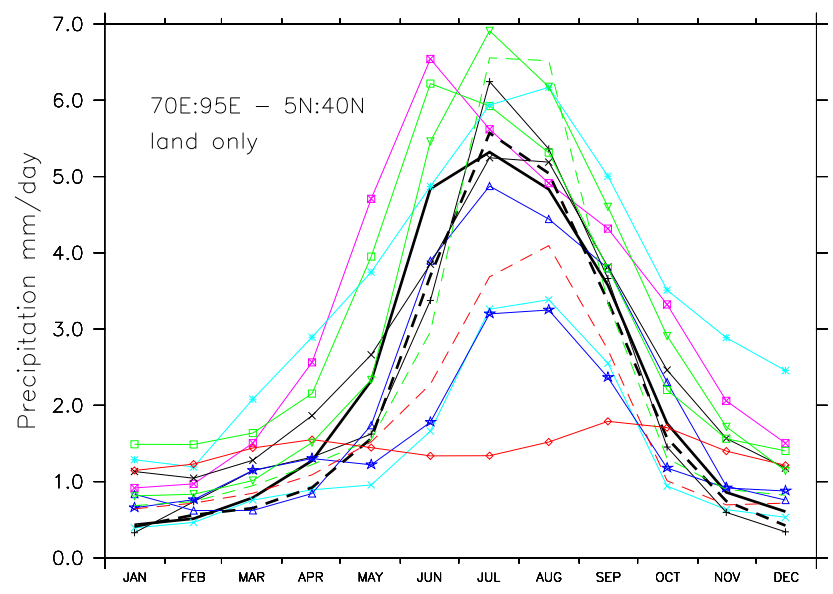

Fig. 2. Precipitation over India and the Himalaya $\left(\mathrm{mmday}^{-1}\right.$, $70^{\circ} \mathrm{E}: 95^{\circ} \mathrm{E}, 5^{\circ} \mathrm{N}: 40^{\circ} \mathrm{N}$ land only). The thick black solid line is for the EC-Earth pre-industrial experiment, the thick black dashed line is for CMAP (Xie and Arkin, 1997). The other lines are for PMIP2 ocean-atmosphere models (pre-industrial). The colours and symbols are the same as in Braconnot et al. (2007a); see their Fig. 10 for a legend and their Table 2 for model characteristics and references. Two models that are included here are not included in Braconnot et al. (2007a): GISS modelE (green dashes, Schmidt et al., 2006) and CSIRO (red dashes, Gordon et al., 2000).
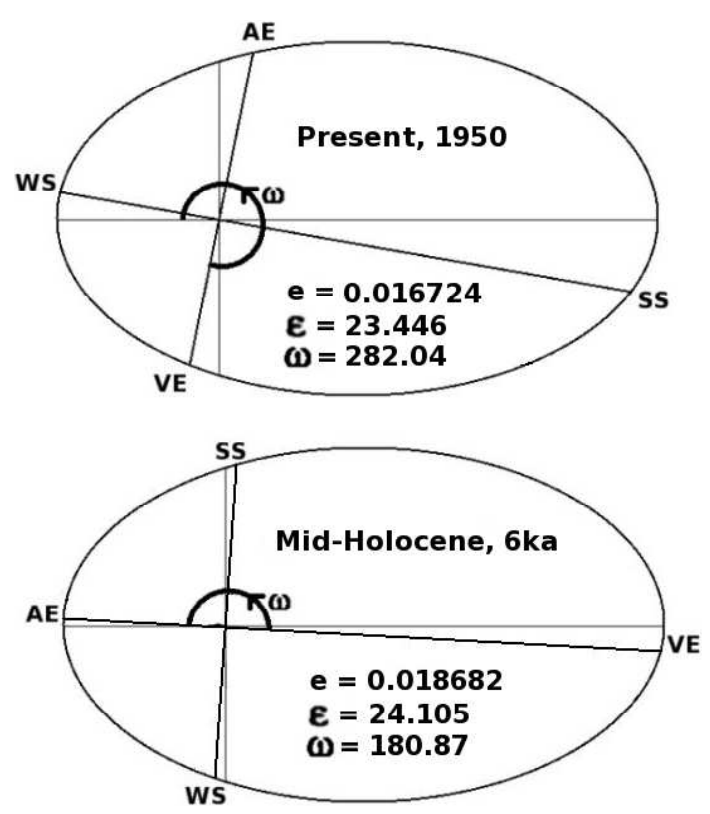

Fig. 3. Present and Mid-Holocene orbit. WS and SS are winter and summer solstice, VE and AE are vernal and autumnal equinox, e is eccentricity, $\varepsilon$ is obliquity and $\omega$ is the longitude of perihelion, defined as the angle between the vernal equinox and perihelion, measured counterclockwise (figure drawn after Joussaume and Braconnot, 1997). 
the boundary conditions as prescribed by PMIP, see http: //pmip3.lsce.ipsl.fr/. This means that CMIP5 pre-industrial boundary conditions are applied for the pre-industrial (PI) experiment, including greenhouse gas concentrations from $1850\left(\mathrm{CO}_{2} 284.5\right.$ ppmv, $\mathrm{CH}_{4} 791.6$ ppbv, $\mathrm{N}_{2} \mathrm{O} 275.7$ ppbv). For the Mid-Holocene (MH) experiment the greenhouse gas concentrations were set to pre-industrial values slightly different from those of $1850\left(\mathrm{CO}_{2} 280 \mathrm{ppmv}, \mathrm{CH}_{4} 650 \mathrm{ppbv}\right.$, $\mathrm{N}_{2} \mathrm{O} 270 \mathrm{ppbv}$ ), but the resulting difference in radiative forcing is negligible compared to the orbitally induced changes in insolation. During the Mid-Holocene, the tilt of the Earth (obliquity) was larger and the orbit was slightly more eccentric than at present. The difference in MH and PI insolation, however, is mostly due to precession. The position closest to the Sun (perihelion) was reached around the time of the autumnal equinox, instead of near the winter solstice at present (Fig. 3). This causes a larger seasonal cycle of insolation on the Northern Hemisphere and a smaller seasonal cycle on the Southern Hemisphere, shown in Fig. 4.

The initial conditions were taken from EC-Earth's CMIP5 pre-industrial experiment, which was run for $730 \mathrm{yr}$ (Hazeleger et al., 2011). The PI and MH experiments discussed here were both performed with version 2.2, including the equations of Berger (1978).

The EC-Earth model is computationally very expensive because of its complexity and high resolution. The PI and MH time-slice experiments were run for $50 \mathrm{yr}$, of which the last $40 \mathrm{yr}$ are used. This is sufficiently long for atmospheric, ocean surface and land processes that are of interest to monsoon dynamics to equilibrate to the changed insolation; trends in surface air temperature, sea surface temperature, the surface heat flux, the top-of-atmosphere net flux and precipitation are shown in Fig. 5. Also, we calculated the globally averaged tendency term of surface air temperature, $\mathrm{d} T / \mathrm{d} t$, which is near-zero (on the order of $10^{-9} \mathrm{~K} \mathrm{yr}^{-1}$ ) and shows no trend in the pre-industrial and Mid-Holocene experiments (not shown).

The EC-Earth model does not (yet) include dynamic vegetation. Vegetation in the MH experiment is the same as in the PI experiment, hence vegetation feedbacks are not included in this study. We set the date of vernal equinox to 21 March and use the present-day calendar, which introduces some errors, mainly in Mid-Holocene autumn insolation, because we do not take into account changes in seasonal length and the dates of equinoxes and solstices, induced by precession (Joussaume and Braconnot, 1997). However, all PMIP experiments use the present-day calendar with the vernal equinox as a reference date in order to facilitate model intercomparison.

\section{Results}

In this section, we describe how the change in insolation affects summer monsoonal precipitation through temperature

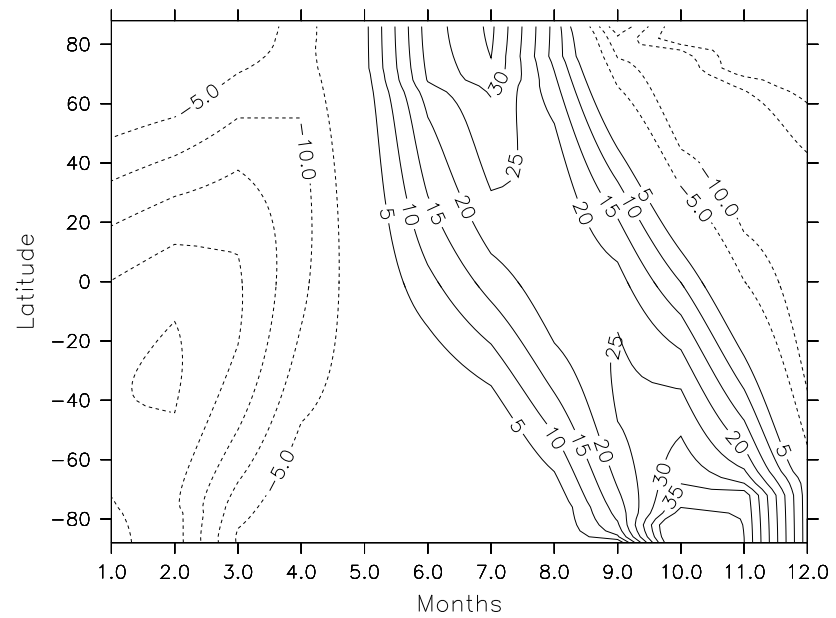

Fig. 4. Insolation difference Mid-Holocene (MH) minus PreIndustrial (PI) in $\mathrm{W} \mathrm{m}^{-2}$, calculated using the equations of Berger (1978).

and pressure gradients, wind fields, moisture advection and vertical motion. Section 3.1 focuses on the North-African monsoon, Sect. 3.2 on the Indian and East-Asian monsoons and the South American monsoon is assessed in Sect. 3.3. For North Africa and Asia we focus on the months JulyAugust-September (JAS), when insolation changes over the $\mathrm{NH}$ tropics are largest. In these three months the precipitation increase is largest as well, but for Asia the absolute precipitation amounts are highest in June-July-August. For South America, we focus on JFM, when the SH insolation decrease is largest, as is the precipitation decrease, while absolute precipitation amounts are highest in DJF. In the figures with colour scales the MH minus PI difference is shown, with the PI climatology given in contours, unless stated otherwise.

\subsection{The North-African monsoon}

During the Mid-Holocene, precipitation over North-Africa was higher than during the pre-industrial, with the largest increase occurring in late summer (Fig. 6a), centred around 10$15^{\circ} \mathrm{N}$ (Fig. 6b). Precipitation over the equatorial Atlantic is reduced, while over land precipitation is not only increased, but also extended further poleward.

To investigate the cause of the precipitation changes, we first examine the changes in surface air temperature, pressure and wind. The increased summer insolation generally results in higher temperatures in the atmosphere and at the surface. Over a large part of North Africa, however, feedbacks from monsoon intensification cause surface air temperatures to decrease (Fig. 7a). Increased cloud cover reduces the surface downward shortwave radiation by $24 \mathrm{~W} \mathrm{~m}^{-2}$ (averaged over $20^{\circ} \mathrm{W}: 40^{\circ} \mathrm{E}, 5^{\circ} \mathrm{N}: 25^{\circ} \mathrm{N}$, land only). The surface latent heat flux to the atmosphere is enhanced by $13 \mathrm{~W} \mathrm{~m}^{-2}$, so increased evaporation over this area also acts 


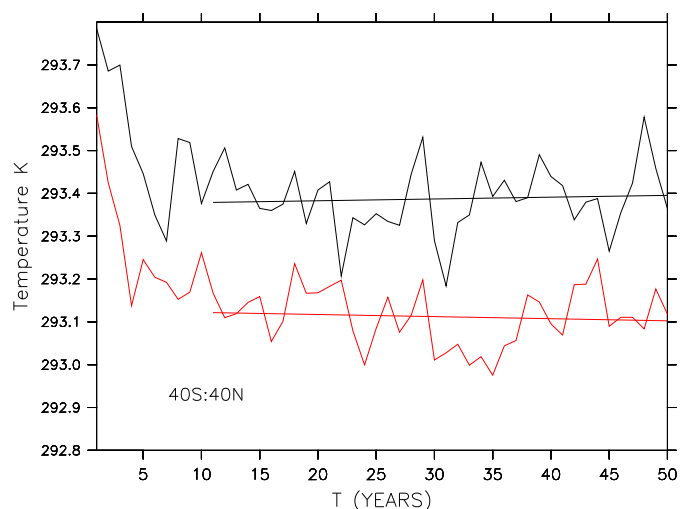

(a) Surface air temperature, $\mathrm{K}$

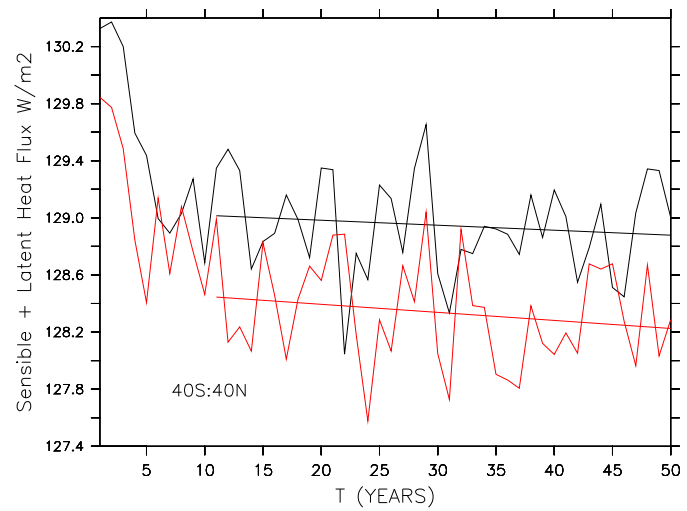

(c) Surface sensible and latent heat flux, $\mathrm{W} / \mathrm{m}^{2}$

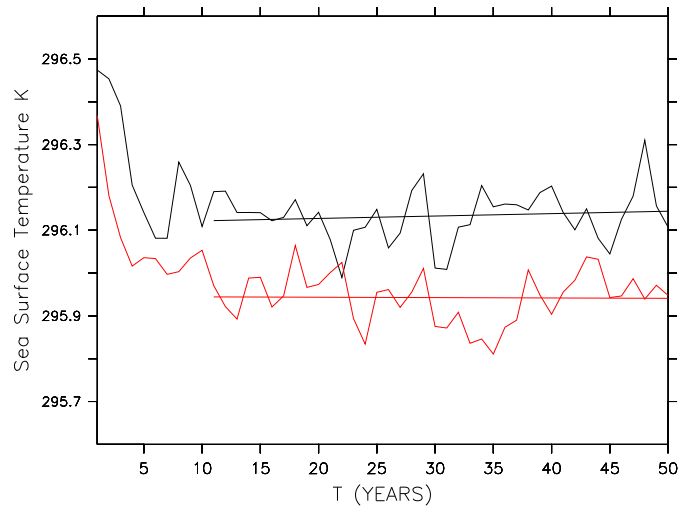

(b) Sea surface temperature, $\mathrm{K}$

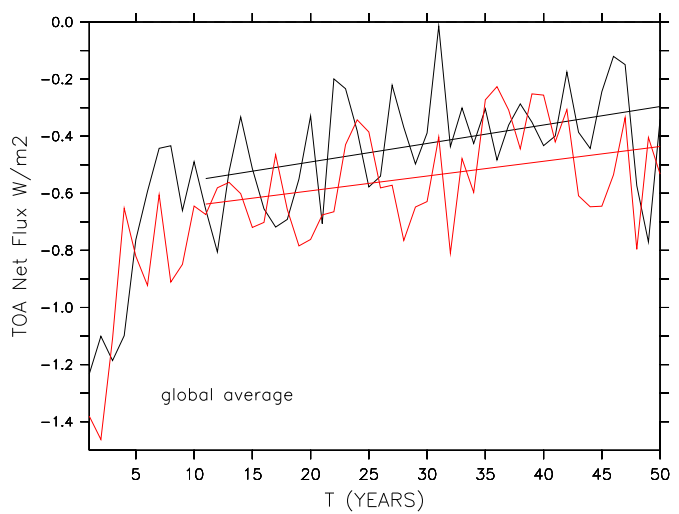

(d) TOA net flux (TSR + OLR), W/m ${ }^{2}$

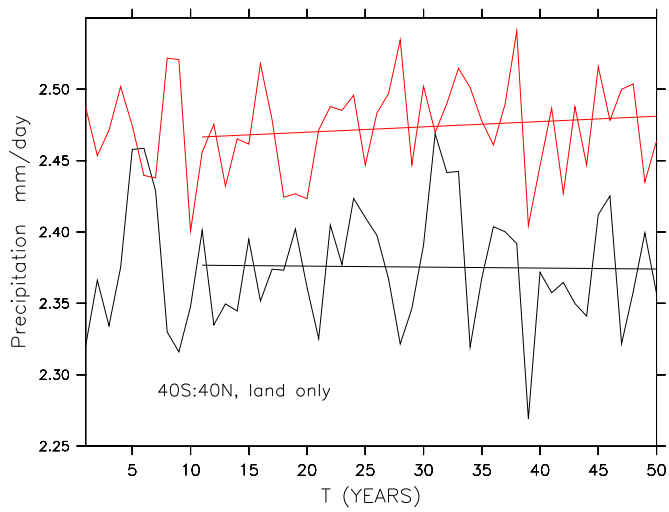

(e) Precipitation, $\mathrm{mm} / \mathrm{day}$

Fig. 5. Trends in the pre-industrial (black) and Mid-Holocene (red) experiments: (a) surface air temperature, (b) sea surface temperature, (c) sum of the surface sensible and latent surface heat flux, (d) net TOA flux (top of atmosphere net short- and longwave) and (e) precipitation. (a), (b), (c) and (e) are $40^{\circ} \mathrm{S}: 40^{\circ} \mathrm{N}$ zonal and annual averages, (e) is over land only, and (d) shows a global annual average. The trend over the last 40 years has been drawn in all figures for both experiments.

to cool the surface. These changes in the surface heat budget are only partly balanced by an increase in surface downward longwave radiation $\left(13 \mathrm{~W} \mathrm{~m}^{-2}\right)$, a decreased sensible heat flux $\left(11 \mathrm{~W} \mathrm{~m}^{-2}\right)$ and a decreased surface upward shortwave radiation $\left(6 \mathrm{~W} \mathrm{~m}^{-2}\right)$. This leaves a deficit of $7 \mathrm{~W} \mathrm{~m}^{-2}$ $(-24-13+13+11+6)$ which explains the surface cooling.
The changes in the surface energy fluxes (summarised in Table 1) are of the same order of magnitude as the insolation forcing (Fig. 4) and more than offset the direct effect of increased insolation, indicating the importance of internal feedbacks in the monsoonal response to insolation changes. Another feedback mechanism operates on the sea surface 


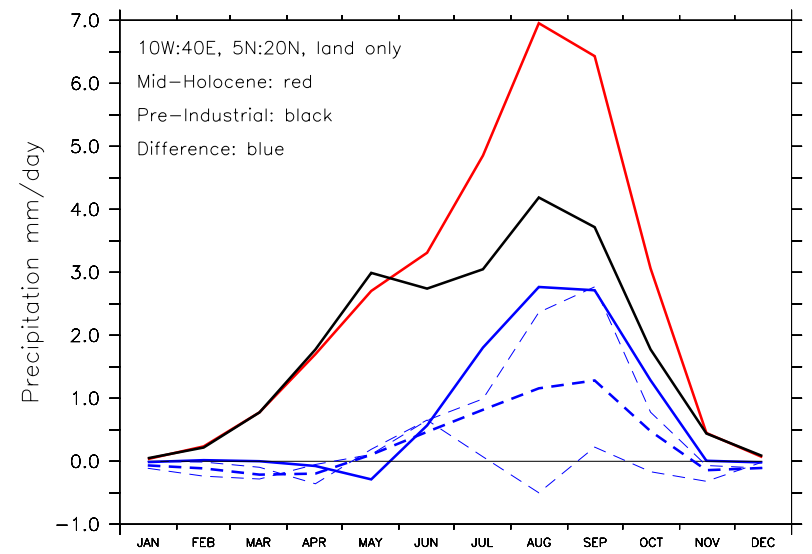

(a) Monthly precipitation over North-Africa, $\mathrm{mm} /$ day

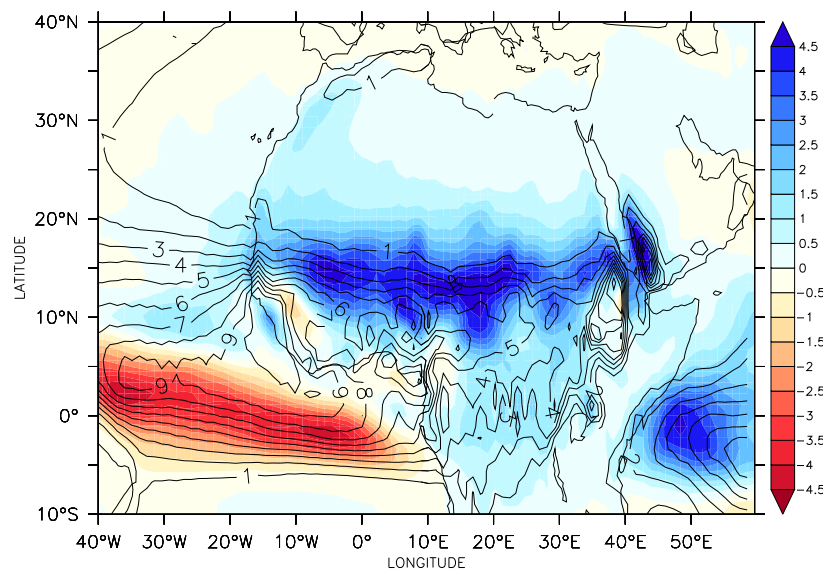

(b) JAS precipitation over North-Africa, $\mathrm{mm} /$ day

Fig. 6. (a) Precipitation $\left(m m d^{-1} y^{-1}\right.$ ) for PI (black), MH (red) and difference MH-PI (blue) throughout the year. The dashed blue lines are differences in the PMIP2 models: the thick dashed blue line is the average of 12 PMIP2 models (see Fig. 15 for references). The thin dashed blue lines are individual PMIP2 model results with the largest and smallest changes for North-Africa in JAS. (b) The spatial pattern of precipitation differences in JAS. Colours indicate MH-PI differences, contours are absolute PI values.

temperatures. These remain relatively cool during summer south of $15^{\circ} \mathrm{N}$, not only because of the delayed response of the ocean due to its large heat capacity, but also because stronger surface monsoon winds act to cool the ocean surface through increased evaporative cooling and upwelling (not shown). This wind-evaporation-SST feedback further enhances the ocean-land temperature gradient (e.g. Zhao et al., 2005).

Changes in surface pressure are more uniform (Fig. 7b). Increased insolation results in lower surface pressure over nearly all of North Africa, especially over the northern Sahara, where the surface air temperature increase is largest and thermal lows arise (Fig. 7a and b). These changes in the pressure gradient are strongly modified by the temperature and precipitation changes and are, therefore, not a passive response to the increased insolation, but involve the feedbacks that lower the surface air temperature over monsoonal North Africa. The enhancement of the meridional pressure gradient intensifies the southerly and south-westerly monsoon winds over the Gulf of Guinea and the equatorial Atlantic, and monsoon winds over the continent extend further north (Fig. 7c and 7d). At $15-20^{\circ} \mathrm{N}$, the northerly trade winds over the Atlantic are more eastward (i.e., landward), and the northerly winds over the coast at $20-30^{\circ} \mathrm{N}$ are weaker in the $\mathrm{MH}$. This is related to the reduced surface pressure at $25^{\circ} \mathrm{N}, 15^{\circ} \mathrm{W}$ (Fig. 7b), which creates a cyclonic pattern in the wind difference field (Fig. 7d). The pressure reduction in the north-eastern Sahara, at $20-30^{\circ} \mathrm{N}$, results in weaker northerly winds over this area.

The next question is where the moisture originates that is necessary to sustain the increased precipitation over North Africa. The precipitation decrease over the equatorial Atlantic (Fig. 6b) and the stronger landward winds over this area (Fig. 7d) strongly suggest that the equatorial Atlantic is the source for increased precipitation over North Africa. This is further supported by changes in evaporation over the ocean, shown in Fig. 8a. South of $10^{\circ} \mathrm{N}-15^{\circ} \mathrm{N}$, enhanced south-westerly winds lead to more evaporation over the ocean, cooling the ocean surface. This wind-evaporationSST feedback, in addition to the precipitation decrease over the equatorial Atlantic, makes more moisture available for transport to the continent. Over land, evaporation is increased north of $15^{\circ} \mathrm{N}$, where the $\mathrm{MH}$ precipitation increase is relatively large because there is virtually no precipitation in the PI (Fig. 6b). Between $5^{\circ} \mathrm{N}$ and $15^{\circ} \mathrm{N}$, where the relative precipitation increase (not shown) is smaller than north of $15^{\circ} \mathrm{N}$, evaporation is decreased in association with lower temperatures in the $\mathrm{MH}$. The small and partly negative changes in evaporation over North Africa indicate that local recycling cannot explain the precipitation increase. A simple calculation of $(\Delta P-\Delta E) / \Delta P$, where $\Delta$ is the MH-PI difference, shows that for $20^{\circ} \mathrm{W}: 40^{\circ} \mathrm{E}, 5^{\circ} \mathrm{N}: 25^{\circ} \mathrm{N}$ (land only) $77 \%$ of the precipitation increase during JAS is due to moisture advection from outside this area. Given the wind pattern, the moisture needed to sustain the increased precipitation over the continent must, therefore, come from the Atlantic Ocean. Moisture advection (defined here as $\boldsymbol{Q}$, the massweighted vertical integral of the product of specific humidity $\boldsymbol{q}$ and the horizontal wind vector $\boldsymbol{v}$, based on 12-hourly model output) is shown in Fig. 8b (MH-PI difference). There is more moisture advection towards the continent between $10^{\circ} \mathrm{N}$ and $20^{\circ} \mathrm{N}$, south of $10^{\circ} \mathrm{N}$ increased landward moisture advection occurs in the lower atmosphere (not shown). This is in agreement with the stronger landward surface winds (Fig. 7d) and enhanced evaporation in the tropical North Atlantic (Fig. 8a). The moisture transport from the east of the Azores High into the north-westernmost part of Africa is reduced (Fig. 8b), despite intensified northerly surface 


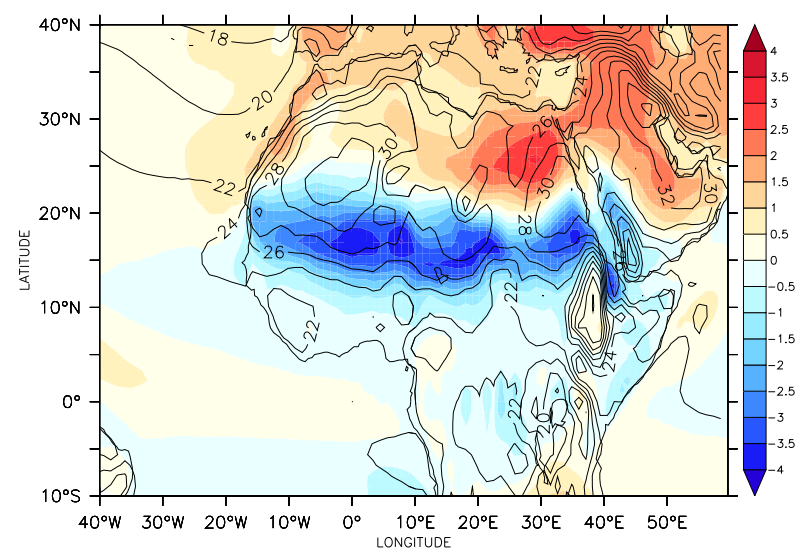

(a) Surface air temperature, ${ }^{\circ} \mathrm{C}$

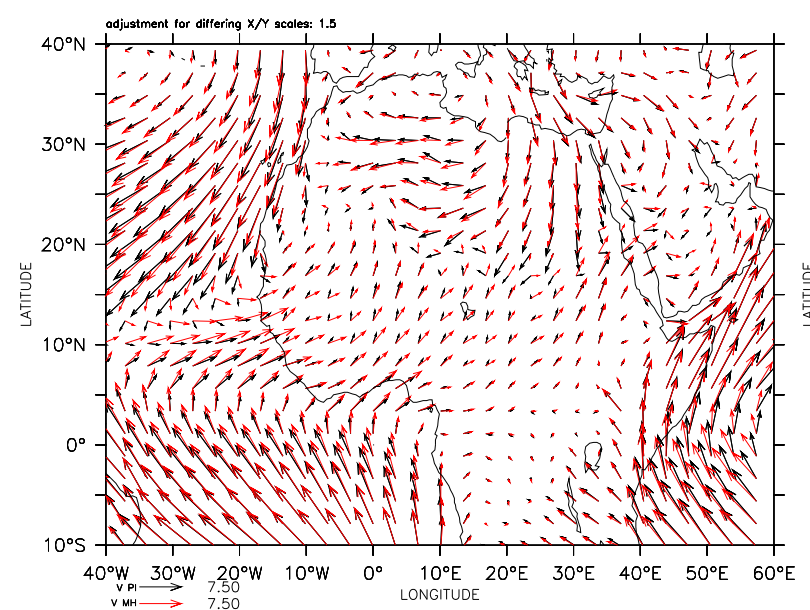

(c) Surface wind field, PI (black), MH (red), m/s

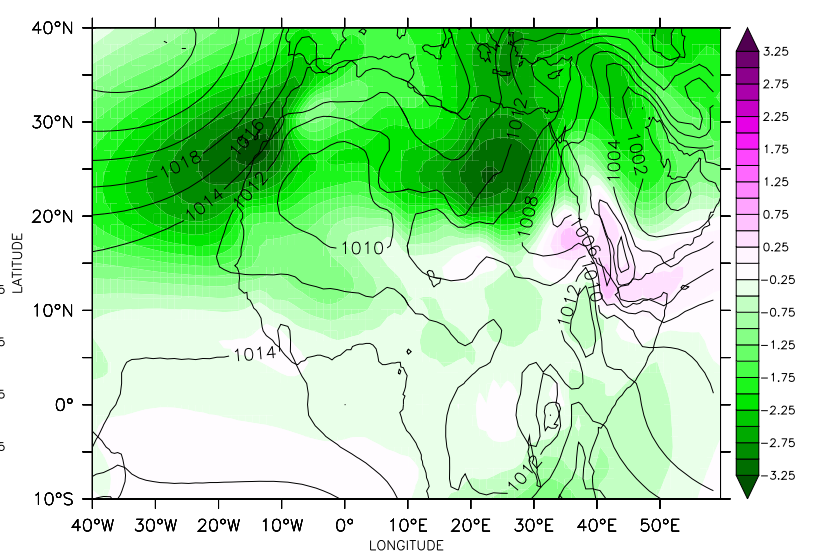

(b) Sea level pressure, $\mathrm{hPa}$

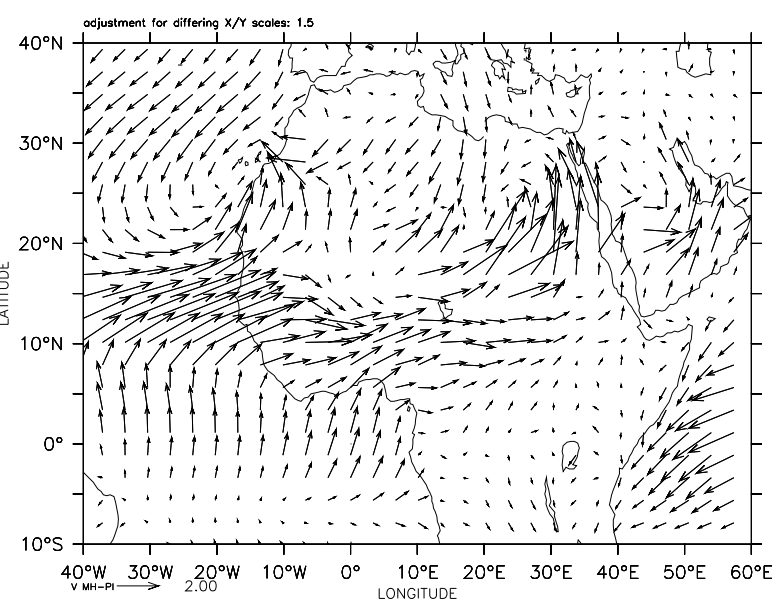

(d) Surface wind difference, $\mathrm{MH}$ - PI, m/s

Fig. 7. MH-PI difference in JAS surface air temperature $-(\mathbf{a}),{ }^{\circ} \mathrm{C}-$ and sea level pressure $-(\mathbf{b})$, hPa; contours are PI values, colours indicate differences between MH and PI. (c) Shows the PI surface wind field (black) and the MH surface wind field (red), unit length is $7.5 \mathrm{~m} \mathrm{~s}^{-1}$, (d) gives the difference between the MH and PI wind field, unit length is $2.0 \mathrm{~m} \mathrm{~s}^{-1}$.

winds over the ocean. At the coast, surface winds become more offshore (Fig. 7d). Over land, southerly winds near $0^{\circ} \mathrm{W}-10^{\circ} \mathrm{W}, 20^{\circ} \mathrm{N}$ are enhanced and moisture advection from the south is increased up to $30^{\circ} \mathrm{N}$. The precipitation increase in western Africa north of $20^{\circ} \mathrm{N}$ could, therefore, be linked to monsoonal precipitation, instead of increased moisture advection from the subtropical Atlantic. Local recycling is also an important factor here, because moisture advection accounts for only $33 \%$ of the precipitation increase over $15^{\circ} \mathrm{W}: 0^{\circ} \mathrm{E}, 25^{\circ} \mathrm{N}: 35^{\circ} \mathrm{N}$ (land only). Both the moisture advection and local recycling lead to enhanced moisture convergence (indicated by net precipitation, P-E) over this area (Fig. 8b). In line with the results presented so far, moisture convergence over the equatorial Atlantic decreased during the Mid-Holocene, in favour of increased moisture convergence over land.

These changes in moisture advection and convergence are linked to changes in the circulation patterns over North Africa. Other model studies have already indicated that the
ITCZ shifts poleward when the insolation forcing is positive (Joussaume et al., 1999; Braconnot et al., 2007a; Marzin and Braconnot, 2009a). Figure 8c shows vertical motion averaged over $40^{\circ} \mathrm{W}: 40^{\circ} \mathrm{E}$, which indicates the location of the ITCZ. Upward motion is weaker over the southern half of the pre-industrial ITCZ, and stronger in the northern half, demonstrating that the ITCZ was located more poleward during the Mid-Holocene. The weakening and northward shift on the southern half of the ITCZ occurs mostly over the ocean, while the stronger upward motion and northward shift on the northern side occurs mostly over land. This spatial pattern is analogous to the changes in vertical motion (not shown), with reduced upward motion and moisture convergence over the ocean and increased upward motion and moisture convergence over land (see Fig. 8b). The decrease in convection centred at $15-20^{\circ} \mathrm{N}, 925 \mathrm{hPa}$ is caused by the northward shift of the convection maximum located here during the PI (contours in Fig. 8c). 


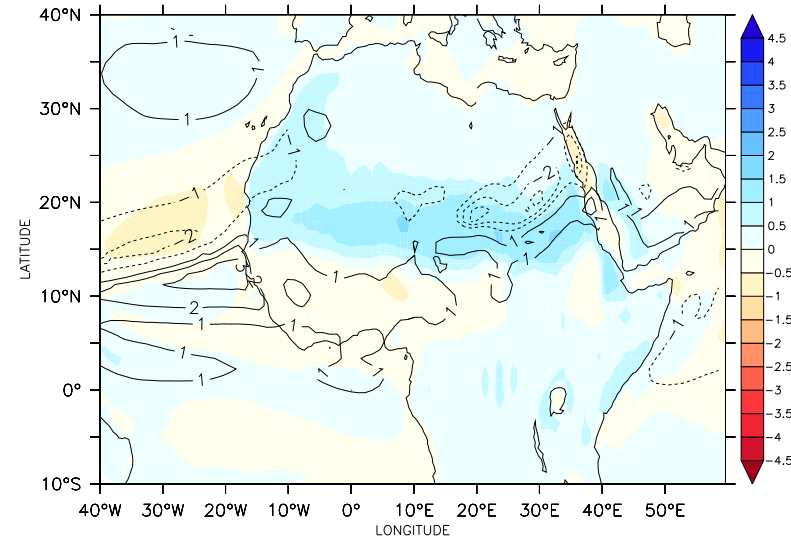

(a) Evaporation, $\mathrm{mm} /$ day (colours) and wind speed, $\mathrm{m} / \mathrm{s}$ (contours), both are MH-PI differences

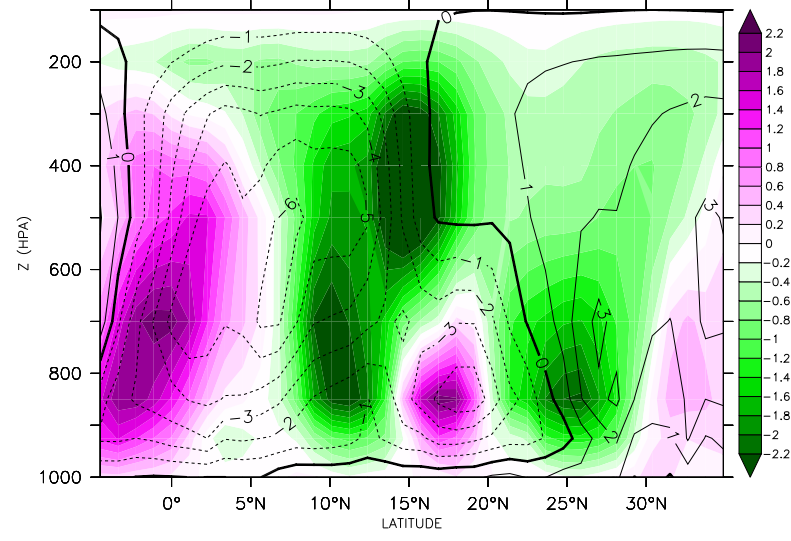

(c) Vertical velocity (omega) $40^{\circ} \mathrm{W}: 40^{\circ} \mathrm{E}, 10^{-2} \mathrm{~Pa} / \mathrm{s}$

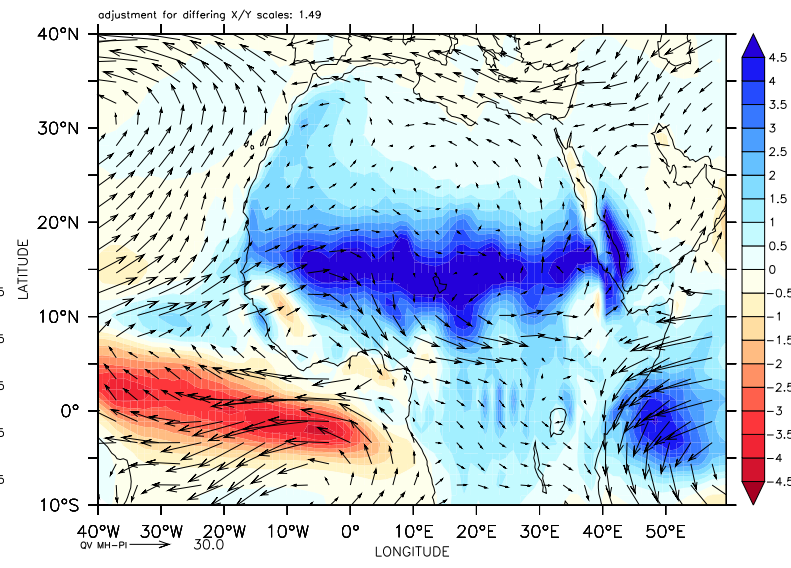

(b) P-E, mm/day (colours) and moisture advection $\boldsymbol{Q}, \mathrm{kg} /(\mathrm{ms})$ (vectors), both are MH-PI differences

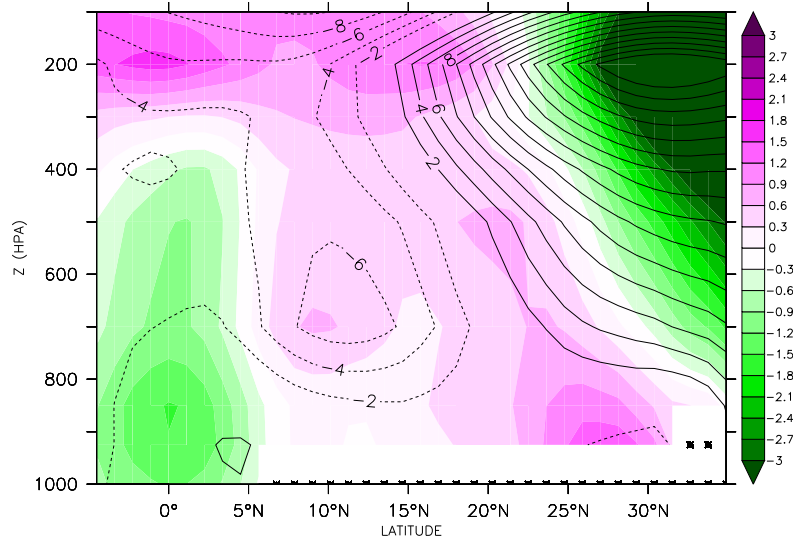

(d) Zonal wind, $0^{\circ} \mathrm{E}, \mathrm{m} / \mathrm{s}$

Fig. 8. MH-PI JAS differences in (a) evaporation (colours, $\mathrm{mm} \mathrm{day}^{-1}$ ) and wind speed (contours, $\mathrm{m} \mathrm{s}^{-1}$ ), (b) P-E (colours, positive values indicating moisture convergence, in mm day ${ }^{-1}$ ) and moisture advection $\boldsymbol{Q}$ (vectors, vector length is $30 \mathrm{~kg} \mathrm{~ms}^{-1}$ ), (c) vertical velocity in $10^{-2} \mathrm{~Pa} \mathrm{~s}^{-1}$, averaged over $40^{\circ} \mathrm{W}: 40^{\circ} \mathrm{E}$ (negative values indicating upward motion), (d) zonal wind velocity in $\mathrm{m} \mathrm{s}^{-1}$ at the meridian $\left(0^{\circ} \mathrm{E}\right)$, positive values are westerly winds. White areas indicate where the pressure levels are below the surface. In panels (c) and $(\mathbf{d})$, colours give the MH-PI difference, contours indicate the PI climatology, and height is given in pressure coordinates, $500 \mathrm{hPa}$ is approximately $5 \mathrm{~km}$.

Over the desert north of the monsoonal area, the downward velocity that characterises this area as the subsidence zone of the Hadley circulation over North Africa is reduced in the MH as the ITCZ shifts northward (Fig. 8c). This results in a weakened Saharan High, a high pressure area in the upper levels (not shown) overlaying the surface low (Fig. 7b). Outflow on the southern side of this pressure ridge is forced westward through the Coriolis force, forming the African Easterly Jet (AEJ, Cook, 1999). In the EC-Earth pre-industrial experiment this jet is situated at approximately $700 \mathrm{hPa}, 10-15^{\circ} \mathrm{N}$. The weakening of the Saharan High during the Mid-Holocene yields a weaker AEJ (Fig. 8d) and, hence, weaker outflow of air from North Africa to the Atlantic at this altitude. Together with increased surface westerlies this enhances the moisture content over Northern Africa.

\subsection{The Indian and East-Asian monsoons}

The model results demonstrate that monsoonal precipitation in Asia was also enhanced as a result of the increased insolation during July, August and September in the Mid-Holocene (Fig. 9a and b). The precipitation increase is largest just south of the Himalayas, where precipitation maxima also occur in the pre-industrial experiment (contour lines in Fig. 9b). The intensified Asian monsoon did not move further northward, as it did over North-Africa. Precipitation increases over land are balanced by precipitation decreases over most of the Indian Ocean and the South Chinese Sea (Fig. 9b).

Changes in surface air temperature over India and SouthEast Asia are small (less than $0.5^{\circ} \mathrm{C}$, Fig. 10a), because the direct warming effect of insolation is offset by increased 


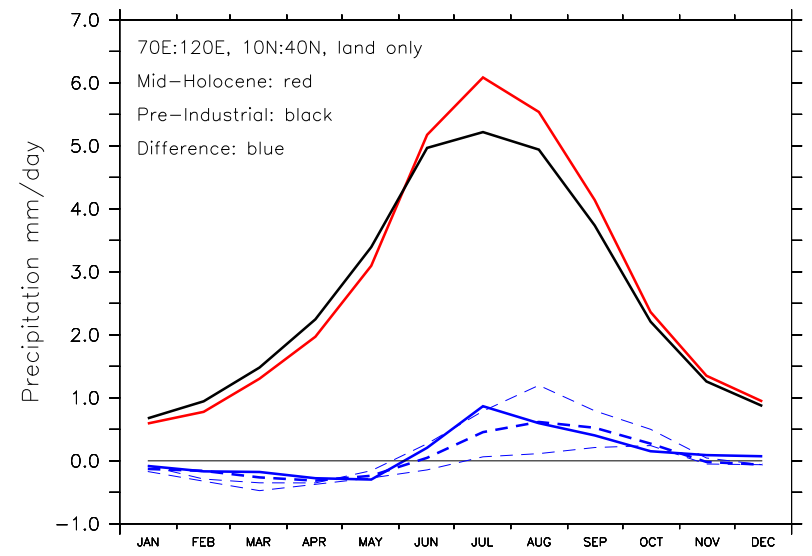

(a) Monthly precipitation over Asia, $\mathrm{mm} /$ day

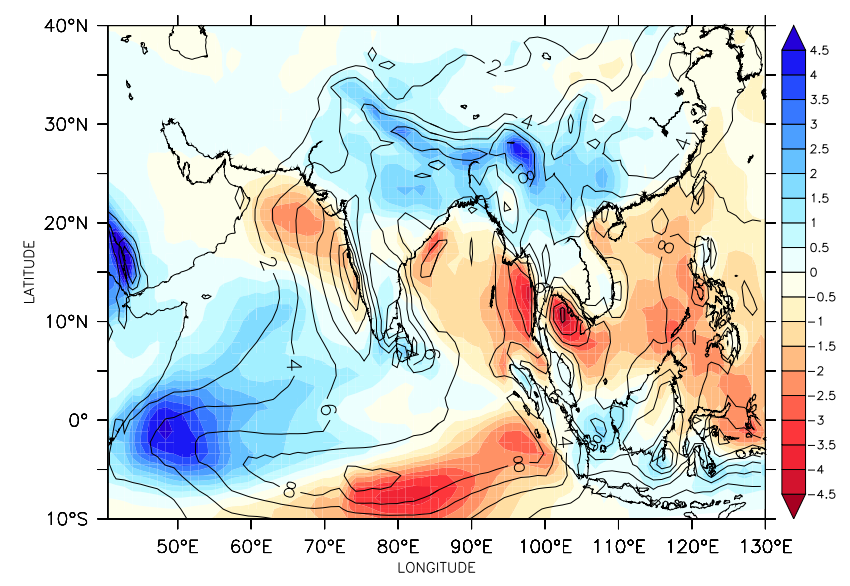

(b) JAS precipitation over Asia, $\mathrm{mm} /$ day

Fig. 9. (a) Precipitation $\left(m m d^{-1} y^{-1}\right.$ ) for PI (black), MH (red) and difference MH-PI (blue) throughout the year. The dashed blue lines are differences in the PMIP2 models: the thick dashed blue line is the average of 12 PMIP2 models (see Fig. 15 for references). The thin dashed blue lines are individual PMIP2 model results with the largest and smallest changes for Asia in JAS. (b) The spatial pattern of precipitation differences in JAS. Colours indicate MH-PI differences, contours are absolute PI values.

cloudiness. Similar to North Africa, the SSRD is lower and the STRD is increased, but the changes are relatively small (see Table 1). Further north, over central Asia, temperatures do increase as a result of increased insolation. This reduces the surface pressure north of $20^{\circ} \mathrm{N}$ (Fig. 10b), reinforcing the meridional pressure gradient north of $20^{\circ} \mathrm{N}$. As a result, the monsoon winds into Asia over the Arabian Sea, the Bay of Bengal and the South China Sea (Fig. 10c and d) are stronger in the Mid-Holocene. Over land, northerly winds are stronger in the monsoonal areas, but they do not penetrate further northward because they are hindered by the Himalayas, which are represented well by the model because of its high resolution. Winds south of $15^{\circ} \mathrm{N}$ are weaker during the $\mathrm{MH}$, associated with the increase of surface pressure over $10-20^{\circ} \mathrm{N}$ (Fig. 10b), which weakens the meridional pressure gradient between the equator and $15^{\circ} \mathrm{N}$. This pressure increase is connected to an intensified high pressure system over the west Pacific (not shown) and contributes to the northward flow along the coasts of eastern India and Vietnam (Zhao et al., 2005).

The increase of the monsoon winds over the Asian coasts is a plausible explanation for the increased precipitation over India and South-East Asia. However, the surrounding oceans do not supply more water during the Mid-Holocene; evaporation is decreased over most of the ocean (Fig. 11a). Between the equator and $10-15^{\circ} \mathrm{N}$ this can be related to decreased wind speeds. Over the areas close to the continent where winds are increased, other feedbacks dominate. Over the Arabian Sea, stronger winds cool the surface through increased upwelling, while over the Bay of Bengal increased river runoff freshens the surface waters and reduces the mixed layer depth (not shown), which reduces evaporation. The only ocean region that provides more moisture to the monsoon flow into Asia is the Indian Ocean south of the equator, where wind speeds and evaporation are increased (Fig. 11a). Over land, in the region where precipitation increases are largest, evaporation changes are mostly negative (Fig. 11a). Also, calculating $(\Delta P-\Delta E) / \Delta P$ for $70: 100^{\circ} \mathrm{E}$, $10: 35^{\circ} \mathrm{N}$ (land-only) reveals that $99 \%$ of the precipitation increase is due to moisture advection, local recycling does not play a role.

The increased evaporation in the southern Indian Ocean is small compared to the precipitation increase over land. Therefore, the redistribution of precipitation from ocean to land (Fig. 9b) must play an important role. This is in agreement with changes in the vertical motion (Fig. 11b): increased moisture convergence and precipitation over the continent is linked to larger upward motions. Over most of the ocean upward motion is weakened, which is in agreement with the higher surface pressure seen in Fig. 10b, resulting in less precipitation. The western equatorial Indian Ocean receives more precipitation in the $\mathrm{MH}$ because of the weakened monsoon southerlies (Fig. 10c and d) and increased convection.

\subsection{The South-American monsoon}

The Southern Hemisphere received less insolation during the Mid-Holocene summer (see Fig. 4). The change in insolation in the tropics and subtropics during summer is of the order $20 \mathrm{~W} \mathrm{~m}^{-2}$ on both hemispheres. On the $\mathrm{SH}$, the insolation decrease is partly offset towards the South Pole by increased obliquity, which acts to increase summer insolation on both hemispheres. Therefore, the summer insolation gradient from equator to pole is weaker on the $\mathrm{SH}$ during the Mid-Holocene, while on the NH it is stronger.

The decreased insolation during the SH summer weakens the South-American monsoon. Figure 12a shows a decrease in precipitation in December-April, especially in a 
Table 1. PI, MH and difference values of the surface energy budget terms (in $\mathrm{W} \mathrm{m}^{-2}$ ), precipitation and evaporation (in $\mathrm{mm} \mathrm{day}^{-1}$ ), over land points only, for North Africa $\left(20^{\circ} \mathrm{W}: 40^{\circ} \mathrm{E}, 5^{\circ} \mathrm{N}: 25^{\circ} \mathrm{N}, \mathrm{JAS}\right)$, Asia $\left(60^{\circ} \mathrm{E}: 120^{\circ} \mathrm{E}, 10^{\circ} \mathrm{N}: 30^{\circ} \mathrm{N}, \mathrm{JAS}\right)$ and South America $\left(40^{\circ} \mathrm{W}: 80^{\circ} \mathrm{W}\right.$, $10^{\circ} \mathrm{S}: 40^{\circ} \mathrm{S}, \mathrm{JFM}$ ). SSRD is surface shortwave radiation downward, STRD is surface thermal (longwave) radiation downward, SLHF is surface latent heat flux, SSHF is surface sensible heat flux, SSRU is surface shortwave radiation upward, STRU is surface thermal (longwave) radiation upward. Positive values of the energy budget terms indicate a flux from the atmosphere towards the surface.

\begin{tabular}{|c|c|c|c|c|c|c|c|c|c|}
\hline & \multicolumn{3}{|c|}{ North Africa } & \multicolumn{3}{|c|}{ Asia } & \multicolumn{3}{|c|}{ South America } \\
\hline & PI & $\mathrm{MH}$ & MH-PI & PI & $\mathrm{MH}$ & MH-PI & PI & $\mathrm{MH}$ & MH-PI \\
\hline SSRD & 252.7 & 228.6 & -24.1 & 191.2 & 188.3 & -2.9 & 225.7 & 221.2 & -4.5 \\
\hline STRD & 369.6 & 382.3 & 12.7 & 382.2 & 386.2 & 4.0 & 362.2 & 356.4 & -5.8 \\
\hline SLHF & -52.2 & -65.3 & -13.1 & -86.2 & -86.2 & 0.0 & -90.4 & -86.5 & 3.9 \\
\hline SSHF & -48.1 & -37.1 & 11.0 & -27.2 & -26.3 & 0.9 & -41.9 & -40.9 & 1.0 \\
\hline SSRU & -66.6 & -60.4 & 6.2 & -31.3 & -30.7 & 0.6 & -33.8 & -33.3 & 0.5 \\
\hline STRU & -454.5 & -447.2 & 7.3 & -427.0 & -428.0 & -1.0 & -420.1 & -416.0 & 4.1 \\
\hline Precip & 3.02 & 4.98 & 1.96 & 5.69 & 6.50 & 0.81 & 5.62 & 5.17 & -0.45 \\
\hline Evap & 1.80 & 2.26 & 0.46 & 2.98 & 2.98 & 0.0 & 3.23 & 3.08 & -0.15 \\
\hline
\end{tabular}

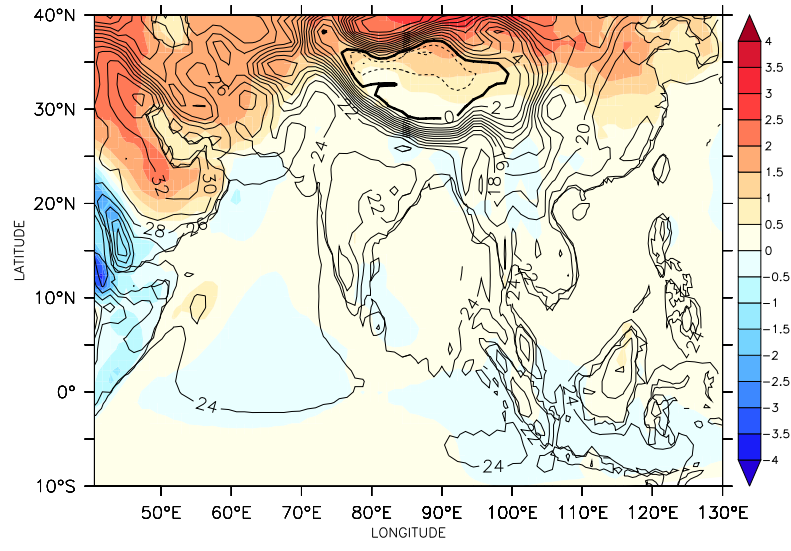

(a) Surface air temperature, ${ }^{\circ} \mathrm{C}$

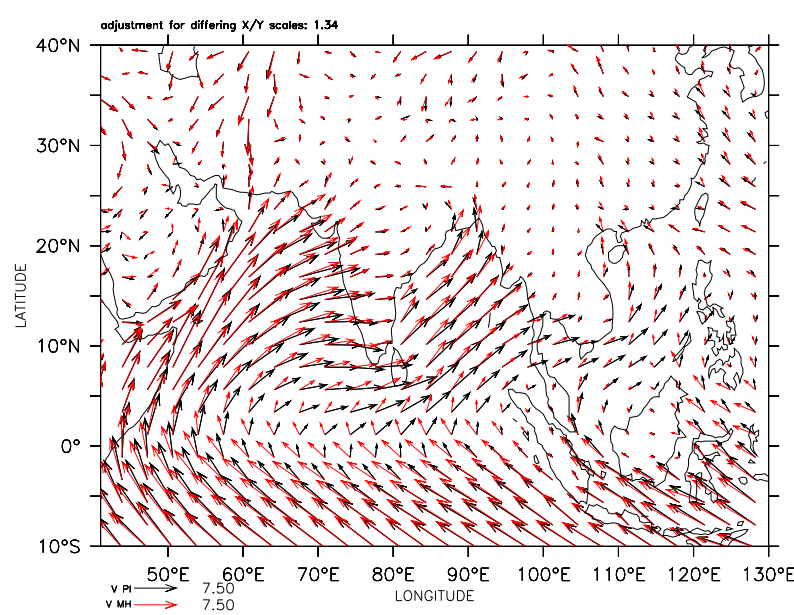

(c) Surface wind field, PI (black), MH (red), m/s

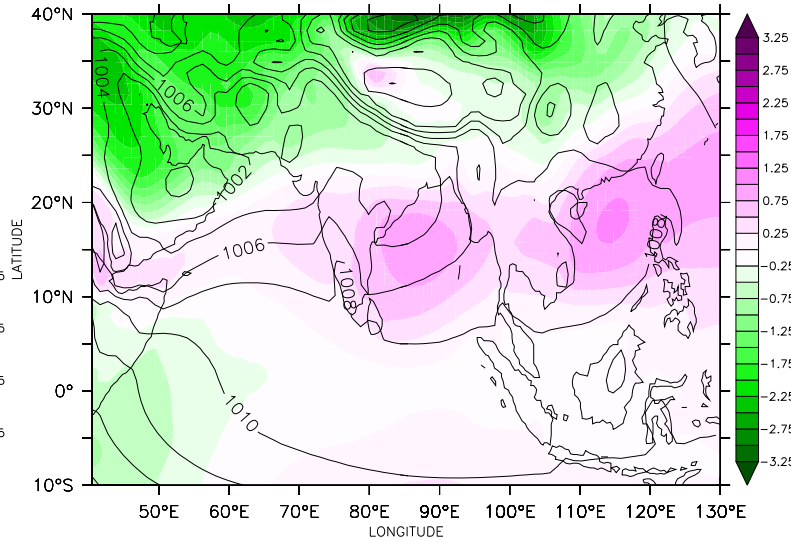

(b) Sea level pressure, $\mathrm{hPa}$

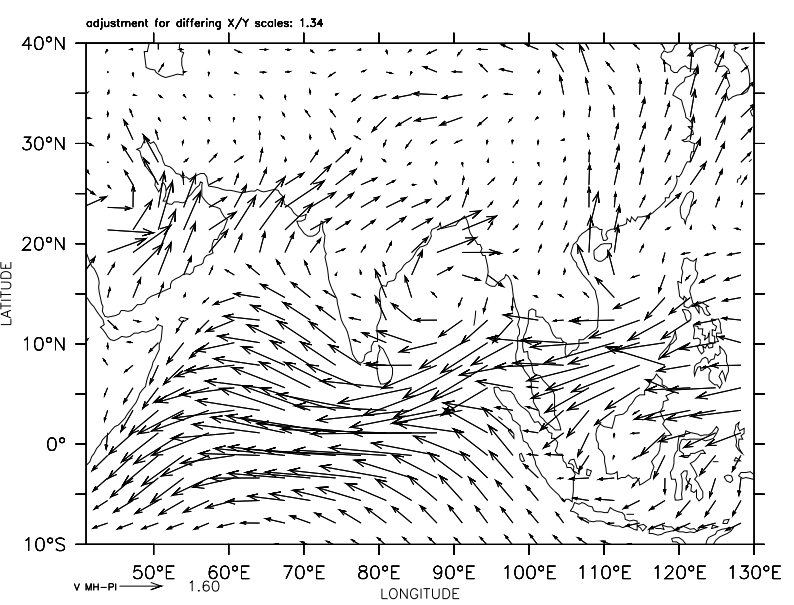

(d) Surface wind difference, $\mathrm{MH}-\mathrm{PI}, \mathrm{m} / \mathrm{s}$

Fig. 10. MH-PI difference in JAS surface air temperature - (a), ${ }^{\circ} \mathrm{C}-$ and sea-level pressure $-(\mathbf{b})$, hPa; contours are PI values, colours indicate differences between MH and PI. (c) Shows the PI surface wind field (black) and the MH surface wind field (red), unit length is $7.5 \mathrm{~m} \mathrm{~s}^{-1}$, (d) gives the difference between the MH and PI wind field, unit length is $1.6 \mathrm{~m} \mathrm{~s}^{-1}$. 


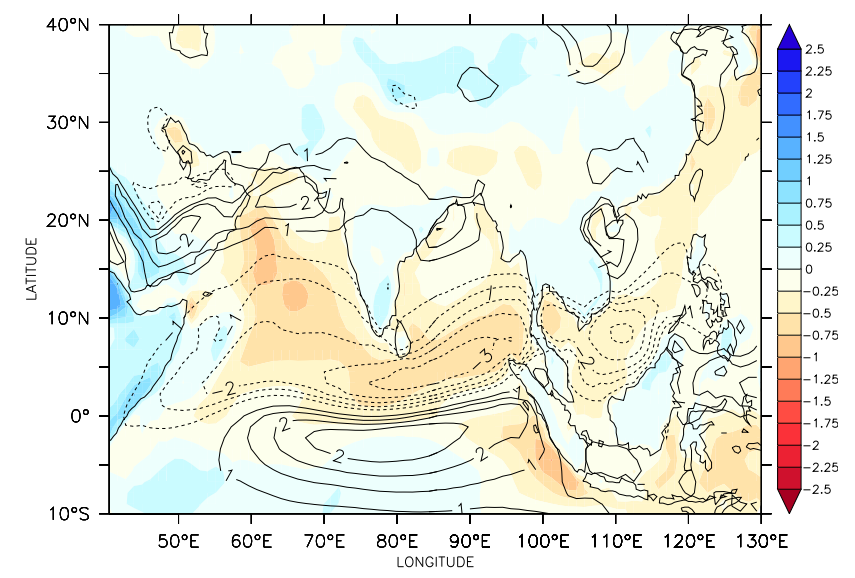

(a) Evaporation, mm/day (colours) and wind speed, $\mathrm{m} / \mathrm{s}$ (contours), both are MH-PI differences

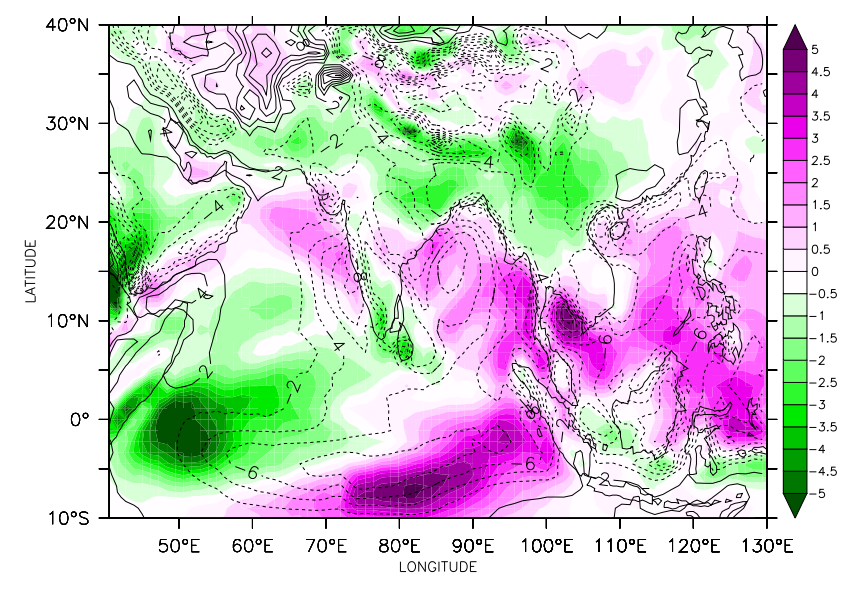

(b) Vertical velocity (omega) at $500 \mathrm{hPa}, 10^{-2} \mathrm{~Pa} / \mathrm{s}$

Fig. 11. MH-PI JAS differences in (a) evaporation (colours, $\mathrm{mm} \mathrm{day}^{-1}$ ) and wind speed (contours, $\mathrm{ms}^{-1}$ ), (b) vertical velocity at $500 \mathrm{hPa}$ in $10^{-2} \mathrm{~Pa} \mathrm{~s}^{-1}$ (negative values indicating upward motion), contours are PI values. $500 \mathrm{hPa}$ is approximately $5 \mathrm{~km}$.

northwest-southeast band over the continent (Fig. 12b, JFM). Over the Atlantic, precipitation is decreased just north of the equator, while the Atlantic between 0 and $20^{\circ} \mathrm{S}$ is wetter.

The precipitation decrease over the South-American continent is consistent with decreased surface air temperatures (Fig. 13a), as a direct consequence of decreased insolation. Table 1 shows that SSRD is decreased, as well as STRD because of reduced cloudiness. Decreased temperatures are associated with a pressure increase over most of the continent (Fig. 13b). The north-easterly monsoon winds are weaker due to the smaller land-sea pressure contrast (Fig. 13c and d). A clockwise pattern is present in the wind difference field around $15^{\circ} \mathrm{S}, 35^{\circ} \mathrm{W}$ (Fig. 13d), where pressure changes are negligible (Fig. 13b), further weakening the monsoons winds around $10^{\circ} \mathrm{S}$ and slightly increasing them at $20^{\circ} \mathrm{S}$.

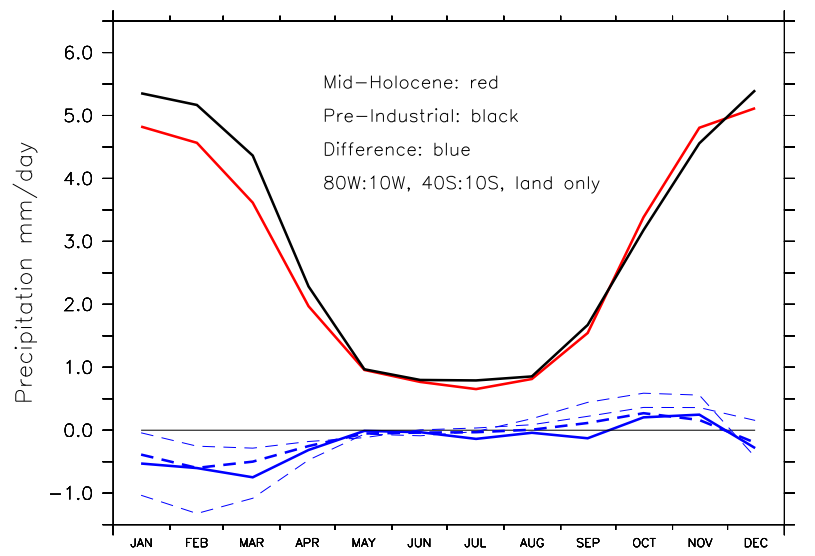

(a) Monthly precipitation over South America, mm/day

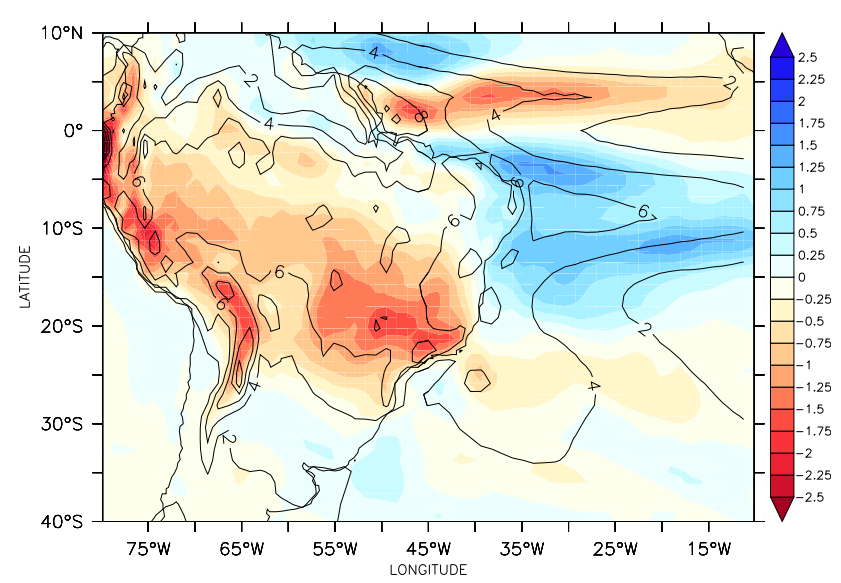

(b) JFM precipitation over South America, mm/day

Fig. 12. (a) Precipitation (mm day ${ }^{-1}$ ) for PI (black), MH (red) and difference MH-PI (blue) throughout the year. The dashed blue lines are differences in the PMIP2 models: the thick dashed blue line is the average of 12 PMIP2 models (see Fig. 15 for references). The thin dashed blue lines are individual PMIP2 model results with the largest and smallest changes for South-America in JFM. (b) The spatial pattern of precipitation differences in JFM. Colours indicate MH-PI differences, contours are absolute PI values. Note that the colour scales are different than for the figures in Sects. 3.1 and 3.2.

The South Atlantic Subtropical High (SASH, centred around $35^{\circ} \mathrm{S}, 5^{\circ} \mathrm{W}$ ) is slightly stronger and located closer to the continent (Fig. 13b), intensifying the easterlies at $20^{\circ} \mathrm{S}$ and the westerlies at $40^{\circ} \mathrm{S}$.

The result of reduced landward winds is a lower transport of moisture to the continent. The weaker surface pressure in the MH over most of the continent decreases convection in a northwest-southeast band over South-America (Fig. 14a), lowering precipitation amounts. Evaporation over land is reduced in the MH as well (not shown) due to lower surface air temperatures and less precipitation. However, the decreased moisture transport to the continent plays a larger role; $(\Delta P-\Delta E) / \Delta P$ is $-70 \%$ over $80^{\circ} \mathrm{W}: 40^{\circ} \mathrm{W}$, $35^{\circ} \mathrm{S}: 5^{\circ} \mathrm{S}$. 


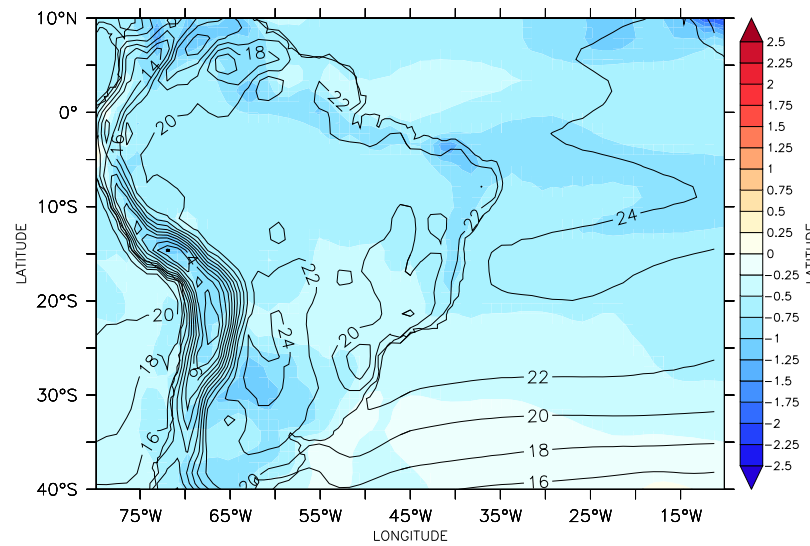

(a) Surface air temperature, ${ }^{\circ} \mathrm{C}$

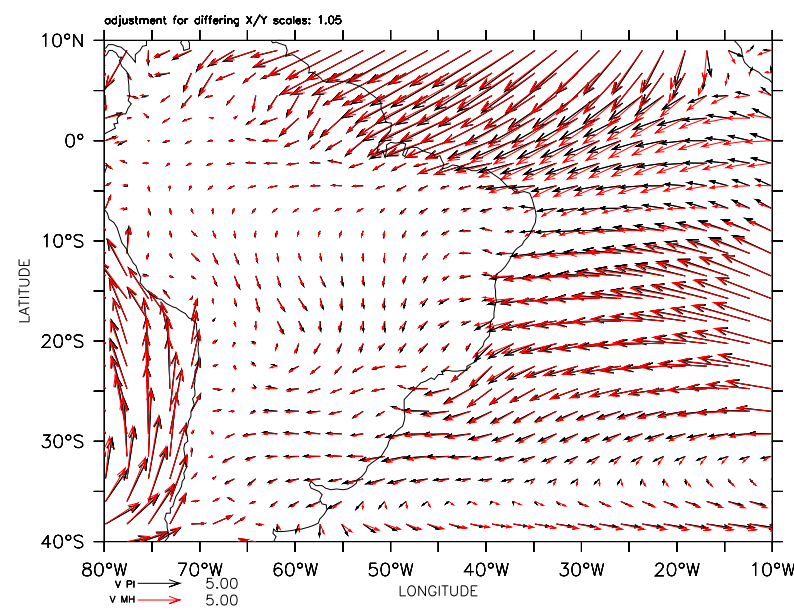

(c) Surface wind field, PI (black), MH (red), $\mathrm{m} / \mathrm{s}$

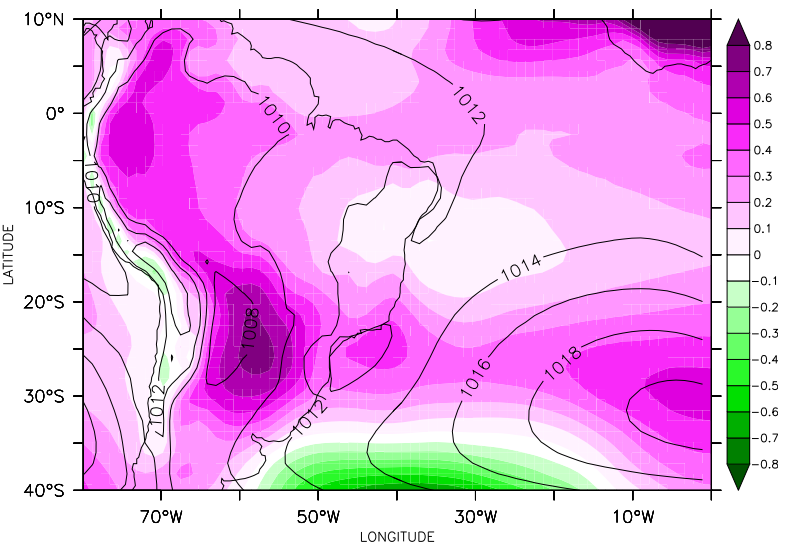

(b) Sea level pressure, $\mathrm{hPa}$

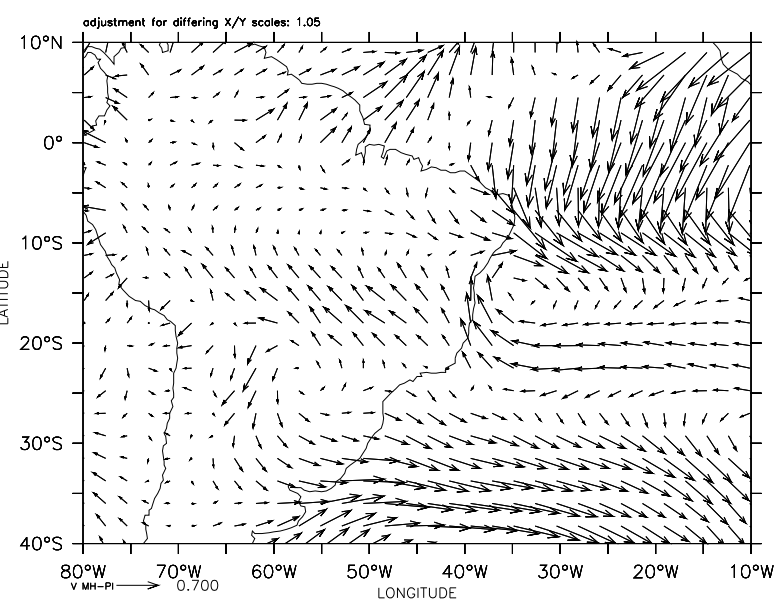

(d) Surface wind field, MH - PI, m/s

Fig. 13. MH-PI difference in JFM surface air temperature - (a), ${ }^{\circ} \mathrm{C}-$ and sea-level pressure - (b), hPa; contours are PI values, colours indicate differences between MH and PI. (c) Shows the PI surface wind field (black) and the MH surface wind field (red), unit length is $5.0 \mathrm{~m} \mathrm{~s}^{-1}$, (d) gives the difference between the MH and PI wind field, unit length is $0.7 \mathrm{~m} \mathrm{~s}^{-1}$. These are JFM averages; note that the scales of the colour bars and vectors are not the same as in Figs. 7 and 9.

Over the ocean, the precipitation increase between $0^{\circ} \mathrm{S}$ and $20^{\circ} \mathrm{S}$ (Fig. 12b) is due to increased upward motion (Fig. 14a) as well as the reduced moisture transport to the continent, leaving more moisture to precipitate out over the ocean. Just north of the equator, precipitation is decreased in response to reduced convection near the coast and increased downward motion further away from the coast (Fig. 14a).

These changes over the ocean can be related to a change in the ITCZ. Figure 14b shows changes in the MH vertical motions with respect to the $\mathrm{PI}$, averaged over $70^{\circ} \mathrm{W}: 10^{\circ} \mathrm{W}$. The northern part of the convective cell at $5-10^{\circ} \mathrm{S}$ is intensified in the lower atmosphere while the downward velocities north of that, around $0-5^{\circ} \mathrm{S}$, are weaker. The DJF average of vertical motion (not shown) demonstrates a northward shift of the ITCZ in the whole atmospheric column, which indicates that the Mid-Holocene ITCZ was located more equatorward during the $\mathrm{SH}$ summer. This is in agreement with the weaker poleward gradient of insolation (Fig. 4).

\section{Discussion}

In this study, we investigated the response of monsoons on both hemispheres to changes in the insolation distribution in the Mid-Holocene with respect to pre-industrial climate, using the EC-Earth model, a high resolution model based on a weather forecast model. The North-African and Asian monsoons were stronger during the Mid-Holocene in response to increased summer insolation, while the South-American monsoon was weaker due to decreased summer insolation. These results corroborate the findings of earlier modelling experiments, most of them summarised in Liu et al. (2004); Zhao et al. (2005); Braconnot et al. (2007a); Wang et al. (2010) and Zhao and Harrison (2011). 


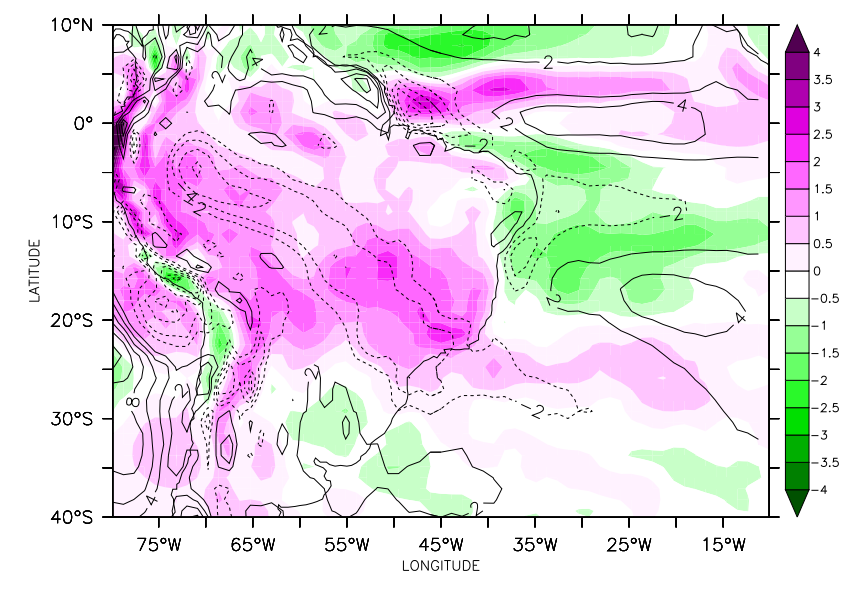

(a) Vertical velocity (omega) at $500 \mathrm{hPa}, 10^{-2} \mathrm{~Pa} / \mathrm{s}$

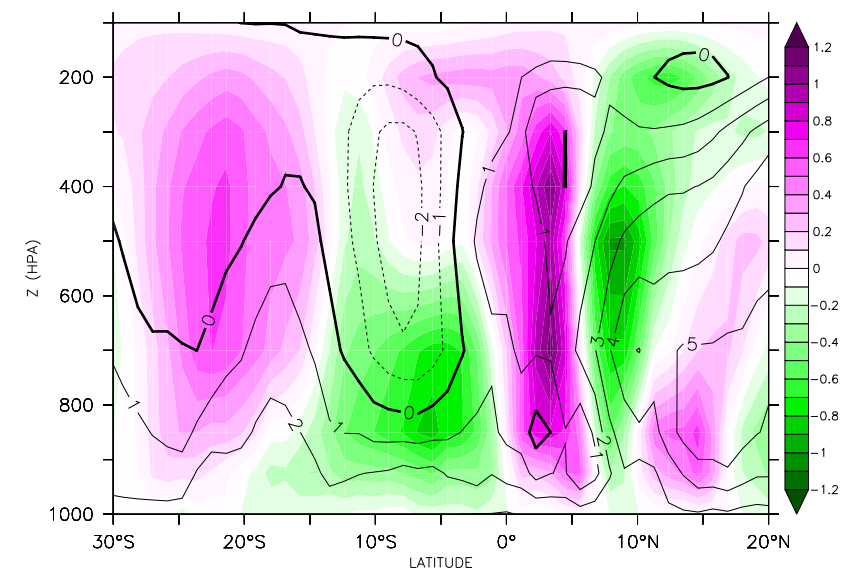

(b) Vertical velocity (omega) $70^{\circ} \mathrm{W}: 10^{\circ} \mathrm{W}, 10^{-2} \mathrm{~Pa} / \mathrm{s}$

Fig. 14. MH-PI JFM difference in (a) vertical velocity at $500 \mathrm{hPa}$ in $10^{-2} \mathrm{Pas}^{-1}$, and (b) vertical velocities averaged over $70^{\circ} \mathrm{W}: 10^{\circ} \mathrm{W}$. Negative values indicate upward motion. Contours are PI JFM values.

\subsection{The North African monsoon}

Over North-Africa, we see an intensified meridional temperature and pressure gradient during the Mid-Holocene summer which allows for a stronger moisture advection from the tropical Atlantic to the continent. Moisture advection plays a larger role than local recycling (in agreement with Zhao et al., 2005; Marzin and Braconnot, 2009a). The pressure gradient is reinforced by internal feedbacks over tropical Africa which decrease surface air temperatures and dampen the pressure response. The lower temperatures over tropical North Africa are also present in PMIP2 results (Braconnot et al., 2007a). Over the Atlantic, a dipole pattern in SSTs exists, with lower SSTs south of $15^{\circ} \mathrm{N}$ due to stronger winds and increased evaporation and higher SSTs north of $15^{\circ} \mathrm{N}$ due to weaker winds and decreased evaporation. This dipole pattern further enhances the meridional temperature and pressure gradients, shifting the ITCZ northward, as has also been reported by Zhao et al. (2005) and Zhao and Harrison (2011), who state the dipole is further south, around $5-10^{\circ} \mathrm{N}$. The northward shift of the ITCZ, which can be inferred from changes in precipitation and vertical velocity, is supported by Liu et al. (2004); Zhao et al. (2005); Braconnot et al. (2007a,b) and Marzin and Braconnot (2009a). The precipitation increase over the continent is also related to a weakening of the African Easterly Jet (AEJ). Texier et al. (2000) and Patricola and Cook (2007) also find a decrease in or disappearance of the AEJ, but only when vegetation feedbacks are included. An atmosphere-ocean experiment without dynamic vegetation in Texier et al. (2000) results in an increased AEJ located further north, as opposed to the the EC-Earth experiments in which the AEJ weakens and remains at the same location.

A notable difference with previous studies is the precipitation increase over north-westernmost Africa. Only two PMIP2 ocean-atmosphere models show a precipitation increase in this region as well (GISS, Schmidt et al., 2006 and UBRIS-HadCM3, Gordon et al., 2000). EC-Earth, GISS and UBRIS all show an increase in southerly winds into northwesternmost North Africa, which in EC-Earth is related to a pressure reduction at $25^{\circ} \mathrm{N}, 10^{\circ} \mathrm{W}$. Southerly moisture advection $\boldsymbol{Q}$ into this area is increased, while north-westerly moisture advection from the Atlantic is decreased. This suggests that the precipitation increase over north-westernmost Africa is monsoonal and is not related to the subtropical Atlantic. However, we cannot exclude that short-lived depressions from the Atlantic had an influence on precipitation over this part of Africa, because these disappear in the averages. Further investigation into the influence of these depressions is beyond the scope of this study. The high resolution and, consequently, the accurate representation of topography could play a role in the precipitation increase over northwesternmost Africa as well: in mid- and eastern North Africa the $\mathrm{MH}$ precipitation does not extend north of the Tibesti and Ahaggar mountains.

The increase and northward shift in precipitation over North Africa in EC-Earth is larger than in most PMIP2 ocean-atmosphere models, as shown in Figs. 6a and 15. Figure 6a shows that the summer precipitation increase over monsoonal North Africa is larger than in any PMIP2 model. The northward shift towards the Sahara is also relatively large compared to PMIP2 models (Fig. 15). This could indicate that a higher resolution and sophisticated parameterizations play a role in reproducing the precipitation pattern for the Mid-Holocene. However, to determine the exact roles of resolution and parameterization, further sensitivity experiments are needed. For EC-Earth this is currently not possible, as no other resolutions or versions similar to the one used here are currently available. 
Despite the relatively large northward shift in precipitation in EC-Earth, this shift is not large enough to sustain the plant types that are known to have occurred during the MidHolocene (Joussaume et al., 1999; Braconnot et al., 2007a). This could be related to the lack of vegetation feedbacks in this study, as both the vegetation cover and albedo is kept at pre-industrial values in both simulations. Vegetation is thought to have a positive feedback on the orbitally induced monsoonal precipitation increase over North Africa through the warming effect of a lowered albedo (Bonfils et al., 2001), an increased sensible heat flux due to increased roughness length and an increased latent heat flux due to increased evapotranspiration (Texier et al., 2000; Levis et al., 2004). The surface warming and increased moisture recycling increase convection and the landward moisture flux. However, there are also studies indicating a negative feedback of vegetation on (annual) precipitation during the Mid-Holocene, when bare soil evaporation was more important and albedo feedbacks played a smaller role due to wetter conditions (Wang et al., 2008; Notaro et al., 2008). Another mechanism that could play a role is the ventilation mechanism (inflow of low moist static energy air, Su and Neelin, 2005; Hales et al., 2006). Further research with dynamic vegetation models and/or sensitivity experiments is necessary to investigate the role of vegetation feedbacks, soil changes, albedo changes and the ventilation effect, as well as the interaction between these effects. Given that the resolution and parameterizations in EC-Earth are good enough to resolve the orography over North-Africa (including the Atlas, Tibesti, Ahaggar and East African mountains) and to capture the present-day precipitation patterns well (Fig. 1), we think that the lack of precipitation over the Sahara in the Mid-Holocene in EC-Earth is not so much related to insufficient resolution or the accuracy of parameterizations, but to the lack of interactive vegetation.

\subsection{The Asian monsoons}

Over Asia, monsoonal precipitation is enhanced as well in response to increased summer insolation. Figure 9a shows that the the amount of precipitation increase in summer over continental Asia is very similar to the increases in PMIP2 models, especially in August and September. In EC-Earth, the largest precipitation increases are along the southern rim of the Himalayas, northern India and southern China. There is little change over northern China and the South-East Asian peninsula. These precipitation changes are broadly in agreement with PMIP2 studies (Braconnot et al., 2007a; Zhao and Harrison, 2011) but patterns vary amongst models (Liu et al., 2004; Zhao et al., 2005; Braconnot et al., 2007a; Marzin and Braconnot, 2009a; Wang et al., 2010). A notable difference between EC-Earth and most PMIP2 models is that the largest precipitation changes are located exactly on the southern rim of the Himalayas, which are represented well at the T159L62 resolution. Models at lower resolutions also represent the Himalayas well, but the precipitation pattern in EC-Earth

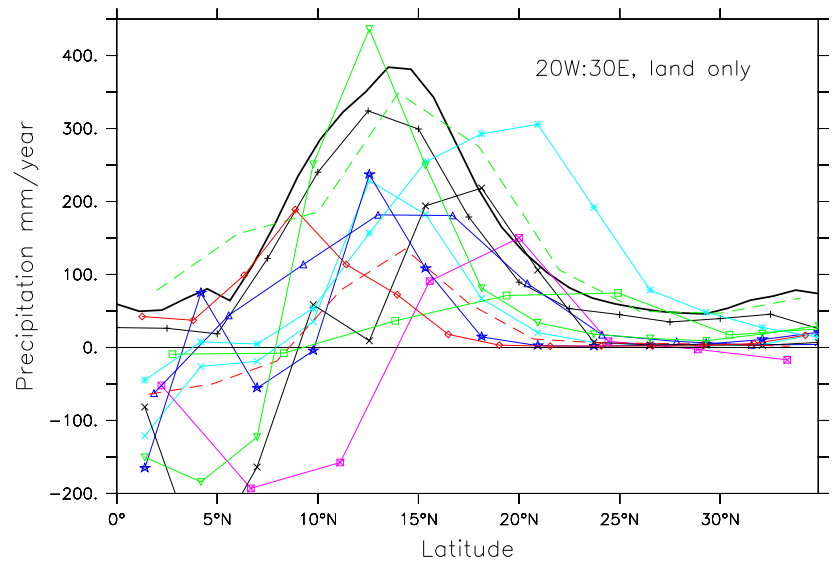

Fig. 15. Annual mean precipitation difference MH-PI over North Africa $\left(20^{\circ} \mathrm{W}: 30^{\circ} \mathrm{E}\right.$, land only). The thick black line is for ECEarth, coloured lines are for PMIP2 ocean-atmosphere models. The colours and symbols are the same as in Braconnot et al. (2007a), Fig. 10. See their Table 2 for model characteristics and references. Two additional models that are included here are: GISS modelE (green dashes, Schmidt et al., 2006) and CSIRO (red dashes, Gordon et al., 2000).

is more detailed than in previous studies. Dallmeyer et al. (2010) also show a precipitation increase on the southern rim of the Himalayas.

In EC-Earth, precipitation increase over continental Asia is mostly related to a redistribution of precipitation between ocean and land, as well as the increased moisture transport from the southern equatorial Indian Ocean (corroborated by Hastenrath, 1991; Clemens et al., 1991; Marzin and Braconnot, 2009a). Local recycling over land does not play a role, which is opposite to the findings of Marzin and Braconnot (2009a) and Dallmeyer et al. (2010). Evaporation over the ocean is lower during the $\mathrm{MH}$ due to increased upwelling over the Arabian Sea and increased runoff in the Bay of Bengal (also described in Marzin and Braconnot, 2009a), as well as reduced wind speeds between the equator and $10-15^{\circ} \mathrm{N}$. These reduced winds are related to increased surface pressure at $10-20^{\circ} \mathrm{N}$, linked to an intensified north-western Pacific subtropical High (Zhao et al., 2005). Stronger winds occur close to the continent over the Arabian Sea, Bay of Bengal, South China Sea and the southern tropical Indian Ocean. This pattern of $\mathrm{MH}$ winds is generally agreed upon amongst models, but the exact pattern and magnitude of winds varies (Texier et al., 2000; Liu et al., 2004; Zhao et al., 2005; Marzin and Braconnot, 2009a,b; Wang et al., 2010; Dallmeyer et al., 2010). The weakened southerly winds in the western Indian Ocean and the associated increased moisture convergence over this area is consistent with previous PMIP results (Braconnot et al., 2007a; Zhao and Harrison, 2011). The only ocean area providing more evaporation is the southern tropical Indian Ocean, where wind speeds are increased. Liu et al. (2004) suggest another ocean feedback that reduces 
the precipitation increase over Asia: increased MH SSTs over the western tropical North Pacific lead to increased convergence and precipitation, competing with convergence and precipitation increases over the Asian continent. This feedback does not occur in the EC-Earth experiments.

\subsection{The South American monsoon}

Over South America, surface air temperatures are lower and surface pressure is higher during the Mid-Holocene as a direct response to the reduced summer insolation. Summer monsoonal precipitation is decreased and the magnitude of this decrease is very similar to that in previous PMIP2 models (Fig. 12a). The precipitation decrease occurs over most of the continent, with the exception of the north-eastern tip of the continent, as a result of weakened monsoon winds and reduced convection. This is consistent with previous model studies (Valdes, 2000; Kitoh and Murakami, 2002; Liu et al., 2004; Dias De Melo and Marengo, 2008). The precipitation increase over the north-eastern coast could be a sign of monsoon retreat, as well as a shift in the ITCZ, because upward motion between the equator and $10^{\circ} \mathrm{S}$ over the Atlantic is stronger as the ITCZ shifts northward in response to a weakened poleward insolation gradient. The South Atlantic Subtropical High is located slightly closer to the continent, which is in agreement with Dias De Melo and Marengo (2008) in their DJF average. Although previous model studies agree on the general pattern of the MH monsoon over South America, more research is required because only two of the studies mentioned here are coupled ocean-atmosphere models (Kitoh and Murakami, 2002; Liu et al., 2004), both using a relatively low resolution.

\subsection{EC-Earth vs. paleodata}

Our results are not only in general agreement with other modelling studies, but also with paleodata. The exception is the lack of precipitation increase over the Sahara, but this is a shortcoming of all ocean-atmosphere models (Braconnot et al., 2007a). Reconstructions of vegetation patterns (e.g. Jolly et al., 1998; Wu et al., 2007; Bartlein et al., 2011) and lake levels (e.g. Yu and Harrison, 1996; Kohfeld and Harrison, 2000) show that North Africa, northern India and South-East Asia were wetter during the Mid-Holocene. An overview of these reconstructions is given in Liu et al. (2004). Reconstructions of precipitation in southern India and South-East Asia are sparse. For China, more reconstructions of temperature and precipitation are available, a summary can be found in Wang et al. (2010), along with the average results of PMIP2 over China. There is some spread amongst models (Zhao et al., 2005; Braconnot et al., 2007a; Marzin and Braconnot, 2009a; Hsu et al., 2010; Wang et al., 2010), but EC-Earth generally agrees with PMIP2 models as well as with paleodata. Temperature is higher, especially towards northern China, and precipitation is increased, especially in south-west China near the Himalayas. One discrepancy is that EC-Earth fails to reproduce the precipitation increase over north-western China.

In South America, lake levels were lower during the MidHolocene (Baker et al., 2001; Sifeddine et al., 2001; Turcq et al., 2002) and studies of pollen and ocean cores show a general drying and imply a more northerly location of the ITCZ (Mayle et al., 2000; Haug et al., 2001; Behling, 2002). These paleodata studies do not clearly indicate wetter conditions in north-east Brazil, which does occur in the ECEarth Mid-Holocene experiment as well as in other models (Valdes, 2000; Kitoh and Murakami, 2002; Liu et al., 2004; Dias De Melo and Marengo, 2008).

Note that these comparisons are based on changes in the model's summer precipitation, whereas most paleodata reconstructions indicate changes in annual precipitation. However, in the monsoon areas discussed here, precipitation barely changes in winter (see Figs. 6a, 9a, 12a) so the summer precipitation changes are a good indication of changes in the annual precipitation.

\section{Conclusions}

Further research is necessary to close the gap between paleodata and climate modelling. The roles of vegetation, soil moisture, albedo, evapotranspiration, the ventilation effect and their combined effect need to be investigated further (Kutzbach et al., 1996; Bonfils et al., 2001; Levis et al., 2004; Su and Neelin, 2005; Patricola and Cook, 2007; Braconnot et al., 2007a; Dallmeyer et al., 2010; Vamborg et al., 2011), especially for North-Africa where models fail to reproduce the northward extend of the monsoon. A higher resolution and sophisticated model parameterization can also help to close the gap between paleodata and models, as indicated by the relatively large northward extend of the North African monsoon in EC-Earth. With this model we have not only contributed to PMIP and confirmed its previous conclusions, we have also obtained an unprecedentedly detailed picture of Mid-Holocene monsoon dynamics and precipitation.

Acknowledgements. The authors would like to thank Dabang Jiang, an anonymous reviewer, and editor Hans Renssen for their constructive remarks on how to improve this article. The authors would also like to thank Pascale Braconnot at the Laboratoire des Sciences du Climate et de l'Environnement (LSCE) for fruitful discussions, and W. J. van de Berg and A. Voldoire for their help with the implementation of the insolation code in EC-Earth. Computing time was provided by the Royal Netherlands Meteorological Institute (KNMI) and the European Centre for Medium-range Weather Forecast (ECMWF). We thank all PMIP-contributors and LSCE for gathering and archiving all PMIP-output. The PMIP2/MOTIF Data Archive is supported by CEA, CNRS the EU project MOTIF and the Programme National d'Etude de la Dynamique du Climat (PNEDC), see http://pmip3.lsce.ipsl.fr/ and http://motif.lsce.ipsl.fr/. For this study, we used the version $11 / 01 / 2010$ of the database. This paper is a contribution to PMIP3. CMAP precipitation data 
is provided by the NOAA/OAR/ESRL PDS, Boulder, Colorado, USA, see http://www.cdc.noaa.gov. Joyce Bosmans is funded by a "Focus en Massa" grant of Utrecht University, The Netherlands.

Edited by: H. Renssen

\section{References}

Baker, P. A., Seltzer, G. O., Fritz, S. C., Dunbar, R. B., Grove, M. J., Tapia, P. M., Cross, S. L., Rowe, H. D., and Broda, J. P.: The History of South American Tropical Precipitation for the Past 25,000 Years, Science, 291, 640-643, doi:10.1126/science.291.5504.640, 2001.

Balsamo, G., Viterbo, P., Beljaars, A., Hurk, B. V. D., Hirschi, M., Betts, A. K., and Scipal, K.: A Revised Hydrology for the ECMWF Model: Verification from Field Site to Terrestrial Water Storage and Impact in the Integrated Forecast System, J. Hydrometeorol., 10, 623-643, doi:10.1175/2008JHM1068.1, 2009.

Bartlein, P. J., Harrison, S. P., Brewer, S., Connor, S., Davis, B. A. S., Gajewski, K., Guiot, J., Harrison-Prentice, T. I., Henderson, A., Peyron, O., Prentice, I. C., Scholze, M., Seppa, H., Shuman, B., Sugita, S., Thompson, R. S., Viau, A. E., Williams, J., and $\mathrm{Wu}, \mathrm{H}$.: Pollen-based continental climate reconstructions at 6 and $21 \mathrm{ka}$ : a global synthesis, Clim. Dynam., 37, 775-802, doi:10.1007/s00382-010-0904-1, 2011.

Bechtold, P. K. M., Jung, T., Doblas-reyes, F., Leutbecher, M., Rodwell, M. J., Vitart, F., and Balsamo, G.: Advances in simulating atmospheric variability with the ECMWF model: From synoptic to decadal time-scales, Q. J. Roy. Meteorol. Soc., 134, 13371351, doi:10.1002/qj.289, 2008.

Behling, H.: South and southeast Brazilian grasslands during Late Quaternary times: a synthesis, Palaeogeogr. Palaeoclimatol., 177, 19-27, 2002.

Berger, A. L.: Long-Term Variations of Daily Insolation and Quaternary Climatic Changes, J. Atmos. Sci., 35, 2362-2367, 1978.

Bonfils, C., de Noblet-Ducoudre, N., Braconnot, P., and Joussaume, S.: Hot Desert Albedo and Climate Change: Mid-Holocene Monsoon in North Africa, J. Climate, 14, 3724-3737, 2001.

Braconnot, P., Joussaume, S., Noblet, N. D., and Ramstein, G.: Mid-Holocene and Last Glacial Maximum African monsoon changes as simulated within the Paleoclimate Modelling Intercomparison Project, Global Planet. Change, 26, 51-66, 2000.

Braconnot, P., Otto-Bliesner, B., Harrison, S., Joussaume, S., Peterchmitt, J.-Y., Abe-Ouchi, A., Crucifix, M., Driesschaert, E., Fichefet, Th., Hewitt, C. D., Kageyama, M., Kitoh, A., Laîné, A., Loutre, M.-F., Marti, O., Merkel, U., Ramstein, G., Valdes, P., Weber, S. L., Yu, Y., and Zhao, Y.: Results of PMIP2 coupled simulations of the Mid-Holocene and Last Glacial Maximum Part 1: experiments and large-scale features, Clim. Past, 3, 261277, doi:10.5194/cp-3-261-2007, 2007a.

Braconnot, P., Otto-Bliesner, B., Harrison, S., Joussaume, S., Peterchmitt, J.-Y., Abe-Ouchi, A., Crucifix, M., Driesschaert, E., Fichefet, Th., Hewitt, C. D., Kageyama, M., Kitoh, A., Loutre, M.-F., Marti, O., Merkel, U., Ramstein, G., Valdes, P., Weber, L., Yu, Y., and Zhao, Y.: Results of PMIP2 coupled simulations of the Mid-Holocene and Last Glacial Maximum Part 2: feedbacks with emphasis on the location of the ITCZ and mid- and high latitudes heat budget, Clim. Past, 3, 279-296, doi:10.5194/cp-3-279-2007, 2007b.
Clemens, S., Prell, W., Murray, D., Shimmield, G., and Weedon, G.: Forcing mechanisms of the Indian Ocean monsoon, Nature, 353, 720-725, 1991.

Cook, K. H.: Generation of the African Easterly Jet and Its Role in Determining West African Precipitation, J. Climate, 12, 11651184, 1999.

Dallmeyer, A., Claussen, M., and Otto, J.: Contribution of oceanic and vegetation feedbacks to Holocene climate change in monsoonal Asia, Clim. Past, 6, 195-218, doi:10.5194/cp-6-1952010, 2010.

Dias De Melo, M. L. and Marengo, J. A.: The Holocene simulation of climate during the mid Holocene The influence of changes in orbital parameters over South American climate using the CPTEC AGCM: simulation of climate during the mid Holocene, Holocene, 18, 501-516, doi:10.1177/0959683608089205, 2008.

Gao, X., Xu, Y., Zhao, Z., Pal, J. S., and Giorgi, F.: On the role of resolution and topography in the simulation of East Asia precipitation, Theor. Appl. Climatol., 86, 173-185, doi:10.1007/s00704-005-0214-4, 2006.

Gordon, C., Cooper, C., Senior, C. A., Banks, H., Gregory, J. M., Johns, T. C., Mitchell, J. F. B., and Wood, R. A.: The simulation of SST, sea ice extents and ocean heat transports in a version of the Hadley Centre coupled model without flux adjustments, Clim. Dynam., 16, 147-168, 2000.

Hales, K., Neelin, J. D., and Zeng, N.: Interaction of Vegetation and Atmospheric Dynamical Mechanisms in the Mid-Holocene African Monsoon, J. Climate, 19, 4105-4120, 2006.

Hastenrath, S.: Regional Circulation Systems, Kluwer Academic Publishers, 1991.

Haug, G. H., Hughen, K. A., Sigman, D. M., Peterson, L. C., and Rohl, U.: Southward Migration of the Intertropical Convergence Zone Through the Holocene Southward Migration of the Intertropical Convergence Zone Through the Holocene, Science, 293, 1304-1308, doi:10.1126/science.1059725, 2001.

Hazeleger, W., Severijns, C., Semmler, T., Ştefănescu, S., Yang, S., Wyser, K., Wang, X., Dutra, E., Baldasano, J. M., Bintanja, R., Bougeault, P., Caballero, R., Ekman, A. M., Christensen, J. H., Hurk, B. V. D., Jimenez, P., Jones, C., Kallberg, P., Koenigk, T., McGrath, R., Miranda, P., Noije, T. V., Palmer, T., Parodi, J. A., Schmith, T., Selten, F., Storelvmo, T., Sterl, A., Tapamo, H., Vancoppenolle, M., Viterbo, P., and Willen, U.: EC-Earth: A Seamless Earth System Prediction Approach in Action, B. Am. Meteorol. Soc., 91, 1357-1363, 2010.

Hazeleger, W., Wang, X., Severijns, C., Ştefănescu, S., Bintanja, R., Sterl, A., Wyser, K., Semmler, T., Yang, W., Hurk, B. v. d., Noije, T. v., Linden, E. v. d., and Wiel, K. v. d.: EC-Earth V2: description and validation of a new seamless Earth system prediction mode, Clim. Dynam., doi:10.1007/s00382-011-1228-5, in press, 2011.

Hsu, Y.-H., Chou, C., and Wei, K.-Y.: Land-Ocean Asymmetry of Tropical Precipitation Changes in the Mid-Holocene, J. Climate, 23, 4133-4151, doi:10.1175/2010JCLI3392.1, 2010.

Jolly, D., Prentice, I. C., Bonnefille, R., Ballouche, A., Bengo, M., Brenac, P., Buchet, G., Burney, D., Cazet, J.-P., Cheddadi, R., Edorh, T., Elenga, H., Elmoutaki, S., Guiot, J., Laarif, F., Lamb, H., Lezine, M., Maley, J., Mbenza, M., Peyron, O., Reille, M., Reynaud, I., Riollet, G., Ritchie, J. C., Roche, E., Scott, L., Ssemmanda, I., Straka, H., Umer, M., Van Campo, E., Vilimumbalo, S., Vincens, A., and Waller, M.: Biome reconstruction 
from pollen and plant macrofossil data for Africa and the Arabian peninsula at 0 and 6000 years, J. Biogeogr., 25, 1007-1027, 1998.

Joussaume, S. and Braconnot, P.: Sensitivity of paleoclimate simulation results to season definitions, J. Geophys. Res., 102, 19431956, 1997.

Joussaume, S., Taylor, K. E., Braconnot, P., Mitchell, F. B., Kutzbach, E., Harrison, S. P., Prentice, I. C., Broccoli, A. J., Abe-Ouchi, A., Bartlein, P. J., Bonfils, C., Dong, B., Guiot, J., Herterich, K., Hewitt, C. D., Jolly, D., Kim, J. W., Kislov, A., Kitoh, A., Loutre, M. F., Masson, V., McAvaney, B., McFarlane, N., Noblet, N. D., Peltier, W. R., Peterschmitt, J. Y., Pollard, I. D., Rind, D., Royer, F., Schlesinger, M. E., Syktus, J., Thompson, S., Valdes, P., Vettoretti, G., Webb, R. S., and Wyputta, U.: Monsoon changes for 6000 years ago: Results of 18 simulations from the Paleoclimate Modeling Intercomparison Project (PMIP), Geophys. Res. Lett., 26, 859-862, 1999.

Kitoh, A. and Murakami, S.: Tropical Pacific climate at the midHolocene and the Last Glacial Maximum simulated by a coupled ocean-atmosphere general circulation model, Paleoceanography, 17, 1-13, doi:10.1029/2001PA000724, 2002.

Kobayashi, C. and Sugi, M.: Impact of horizontal resolution on the simulation of the Asian summer monsoon and tropical cyclones in the JMA global model, Clim. Dynam., 93, 165-176, doi:10.1007/s00382-004-0427-8, 2004.

Kohfeld, K. E. and Harrison, S. P.: How well can we simulate past climates? Evaluating the models using global palaeoenvironmental datasets, Quaternary Sci. Rev., 19, 321-345, 2000.

Kutzbach, J. E. and Guetter, P. J.: The Influence of Changing Orbital Parameters and Surface Boundary Conditions on Climate Simulations for the Past 18000 years, J. Atmos. Sci., 43, 17261759, 1986.

Kutzbach, J. E. and Otto-Bliesner, B. L.: The Sensitivity of the African-Asian Monsoonal Climate to Orbital Parameter Changes for 9000 Years B.P. in a Low-Resolution General Circulation Model, J. Atmos. Sci., 39, 1177-1188, 1982.

Kutzbach, J. E., Bonan, G. B., Foley, J., and Harrison, S. P.: Vegetation and soil feedbacks on the response of the African monsoon to orbital forcing in the early to middle Holocene, Nature, 384, 623-626, 1996.

Lal, M., Cubasch, U., Perlwitz, J., and Waszkewitz, J.: Simulation of the Indian monsoon climatology in ECHAM3 climate model: sensitivity to horizontal resolution, Int. J. Climatol., 17, 847-858, 1997.

Levis, B. S., Bonan, G. B., and Bonfils, C.: Soil feedback drives the mid-Holocene North African monsoon northward in fully coupled CCSM2 simulations with a dynamic vegetation model, Clim. Dynam., 23, 791-802, doi:10.1007/s00382-004-0477-y, 2004.

Liu, Z., Harrison, S. P., Kutzbach, J., and Otto-Bliesner, B.: Global monsoons in the mid-Holocene and oceanic feedback, Clim. Dynam., 22, 157-182, doi:10.1007/s00382-003-0372-y, 2004.

Madec, G: NEMO ocean engine, Note du Pole de modlisation, Institut Pierre-Simon Laplace (IPSL), Paris, France, No. 27, ISSN No. 1288-1618, 2008.

Marchant, R., Cleef, A., Harrison, S. P., Hooghiemstra, H., Markgraf, V., van Boxel, J., Ager, T., Almeida, L., Anderson, R., Baied, C., Behling, H., Berrio, J. C., Burbridge, R., Björck, S., Byrne, R., Bush, M., Duivenvoorden, J., Flenley, J., De Oliveira,
P., van Geel, B., Graf, K., Gosling, W. D., Harbele, S., van der Hammen, T., Hansen, B., Horn, S., Kuhry, P., Ledru, M.P., Mayle, F., Leyden, B., Lozano-García, S., Melief, A. M., Moreno, P., Moar, N. T., Prieto, A., van Reenen, G., SalgadoLabouriau, M., Schäbitz, F., Schreve-Brinkman, E. J., and Wille, M.: Pollen-based biome reconstructions for Latin America at 0, 6000 and 18000 radiocarbon years ago, Clim. Past, 5, 725-767, doi:10.5194/cp-5-725-2009, 2009.

Markgraf, V.: Climatic History of Central and South America since 18,000 yr B.P.: Comparison of Pollen Records and Model Simulations, University of Minnesota Press, available at: http://books. google.nl/books?id=c93dGzg8vM8C (last access: July 2011), 1993.

Marzin, C. and Braconnot, P.: Variations of Indian and African monsoons induced by insolation changes at 6 and $9.5 \mathrm{kyr} \mathrm{BP}$, Clim. Dynam., 33, 215-231, doi:10.1007/s00382-009-0538-3, 2009a.

Marzin, C. and Braconnot, P.: The role of the ocean feedback on Asian and African monsoon variations at $6 \mathrm{kyr}$ and $9.5 \mathrm{kyr} \mathrm{BP}$, Geoscience, 341, 643-655, doi:10.1016/j.crte.2009.09.001, 2009b.

Masson, V. and Joussaume, S. J.: Energetics of the 6000-yr BP Atmospheric Circulation in Boreal Summer, from LargeScale to Monsoon Areas: A Study with Two Versions of the LMD AGCM, J. Climate, 10, 2888-2903, 1997.

Mayle, F. E., Burbridge, R., and Killeen, T. J.: Millennial-Scale Dynamics of Southern Amazonian Rain Forests, Science, 290, 2291-2294, doi:10.1126/science.290.5500.2291, 2000.

Notaro, C., Wang, Y., Liu, Z., Gallimore, R., and Levis, S.:Combined statistical and dynamical assessment of simulated vegetation-rainfall interactions in North Africa during the MidHolocene, Global Change Biol., 14, 347-368, 2008.

Ohgaito, R. and Abe-Ouchi, A.: The role of ocean thermodynamics and dynamics in Asian summer monsoon changes during the mid-Holocene, Clim. Dynam., 29, 39-50, doi:10.1007/s00382006-0217-6, 2007.

Patricola, C. M. and Cook, K. H.: Dynamics of the West African Monsoon under Mid-Holocene Precessional Forcing: Regional Climate Model Simulations, J. Climate, 20, 694-716, doi:10.1175/JCLI4013.1, 2007.

Ruddiman, W. F.: Earth's Climate: Past and Future, W. H. Freeman, http://books.google.nl/books?id=Mpj_GwAACAAJ (last access: June 2011), 2007.

Schmidt, G., Ruedy, R., Hansen, J. E., Aleinov, I., Bell, N., Bauer, M., Bauer, S., Cairns, B., Canuto, V., Cheng, Y., Del Genio, A., Faluvegi, G., Friend, A. D., Hall, T. M., Hu, Y., Kelley, M., Kiang, N. Y., Koch, D., Lacis, A., Lerner, J., Lo, K. K., Miller, R. L., Nazarenko, L., Oinas, V., Perlwitz, J., Perlwitz, J., Rind, D., Romanou, A., Russel, G. L., Sato, M., Shindell, D. T., Stone, P. H., Sun, S., Tausnev, N., Thresher, D., and Yao, M.S.: Present-Day Atmospheric Simulations Using GISS ModelE: Comparison to In Situ, Satellite, and Reanalysis Data, J. Climate, 19, 153-192, 2006.

Shukla, J.: Interannual Variability of Monsoons, Wiley Interscience, 1987.

Sifeddine, A., Martin, L., Turcq, B., Volkmer-Ribeiro, C., Soubie, F., Campello Cordeira, R., and Suguio, K.: Variations of the Amazonian rainforest environment: a sedimentological record covering 30,000 years, Palaeogeogr. Palaeocl., 168, 221-235, 
2001.

Sperber, K. R., Hameed, S., Potter, G. L., and Boyle, J. S.: Simulation of the Northern Summer Monsoon in the ECMWF Model: Sensitivity to Horizontal Resolution, Mon. Weather Rev., 122, 2461-2481, 1994.

Sterl, A., Bintanja, R., Brodeau, L., Gleeson, E., Koenigk, T., Schmidt, T., Semmler, T., Severijns, C., Wyser, K., and Yang, S.: A look at the ocean in the EC-Earth climate model, Clim. Dynam., accepted, doi:10.1007/s00382-011-1239-2, in press, 2011.

Street-Perrott, F. A. and Perrot, R. A.: Holocene Vegetation, Lake Levels, and Climate of Africa, University of Minnesota Press, available at: http://books.google.nl/books?id=c93dGzg8vM8C (last access: July 2011), 1993.

$\mathrm{Su}, \mathrm{H}$. and Neelin, J. D.: Dynamical mechanisms for African monsoon changes during the mid-Holocene, J. Geophys. Res., 110, D19105, doi:10.1029/2005JD005806, 2005.

Texier, D., Noblet, N. D., and Braconnot, P.: Sensitivity of the African and Asian Monsoons to Mid-Holocene Insolation and Data-Inferred Surface Changes, J. Climate, 13, 164-181, 2000.

Turcq, B., Albuquerque, A. L. S., Cordeiro, R. C., Sifeddine, A., Simoes Filho, F. F. L., Souza, A. G., Abrao, J. J., Oliveira, F. B. L., Silva, A. O., and Capita, J.: Accumulation of organic carbon in five Brazilian lakes during the Holocene, Sediment. Geol., 148, 319-342, 2002.

Valcke, S.: OASIS3 user guide, PRISM Tech. Rep. 3, 68 pp., available online at http://www.prism/enes.org/Publications/Reports/ oasis3_UserGuide_T3.pdf (last access: March 2012), 2006.

Valdes, P. J.: South American palaeoclimate model simulations: how reliable are the models?, J. Quaternary Sci., 15, 357-368, 2000.

Vamborg, F. S. E., Brovkin, V., and Claussen, M.: The effect of a dynamic background albedo scheme on Sahel/Sahara precipitation during the mid-Holocene, Clim. Past, 7, 117-131, doi:10.5194/cp-7-117-2011, 2011.

Wang, Y., Notaro, M., Liu, Z., Gallimore, R., Levis, S., and Kutzbach, J. E.: Detecting vegetation-precipitation feedbacks in mid-Holocene North Africa from two climate models, Clim. Past, 4, 59-67, doi:10.5194/cp-4-59-2008, 2008.

Wang, T., Wang, H. J., and Jiang, D.: Mid-Holocene East Asian summer climate as simulated by the PMIP2 models, Palaeogeogr. Palaeocl., 288, 93-102, doi:10.1016/j.palaeo.2010.01.034, 2010.
Webster, P. J.: The Elementary Monsoon, Wiley Interscience, 1987a.

Webster, P. J.: The Variable and Interactive Monsoon, Wiley Interscience, $1987 \mathrm{~b}$.

Webster, P. J., Magana, V. O., Palmer, T. N., Shukla, J., Tomas, R. A., Yanai, M., and Yasunari, T.: Monsoons: Processes, predictability, and the prospects for prediction 2 . Description of the Monsoons, J. Geophys. Res., 103, 451-510, 1998.

Winkler, M. G. and Wang, P. K.: The Late-Quaternary Vegetation and Climate of China, University of Minnesota Press, available at: http://books.google.nl/books?id=c93dGzg8vM8C (last access: July 2011), 1993.

Wu, H., Guiot, J., Brewer, S., and Guo, Z.: Climatic changes in Eurasia and Africa at the last glacial maximum and mid-Holocene: reconstruction from pollen data using inverse vegetation modelling, Clim. Dynam., 29, 211-229, doi:10.1007/s00382-007-0231-3, 2007.

Xie, P. and Arkin, P. A.: Global Precipitation: A 17-Year Monthly Analysis Based on Gauge Observations, Satellite Estimates, and Numerical Model Outputs, B. Am. Meteorol. Soc., 78, 25392558, 1997.

Yu, G. and Harrison, S. P.: An evaluation of the simulated water balance of Eurasia and northern Africa at 6000 y BP using lake status data, Clim. Dynam., 12, 723-735, 1996.

Yu, G., Prentice, I. C., Harrison, S. P., and Sun, X.: Pollen-based biome reconstructions for China at 0 and 6000 years, J. Biogeogr., 25, 1055-1069, 1998.

Zhao, Y. and Harrison, S. P.: Mid-Holocene monsoons: a multimodel analysis of the inter-hemispheric differences in the responses to orbital forcing and ocean feedbacks, Clim. Dynam., 1-31, doi:10.1007/s00382-011-1193-z, in press, 2011.

Zhao, Y., Braconnot, P., Marti, O., Harrison, S. P., Hewitt, C., Kitoh, A., Liu, A., Mikolajewicz, U., Otto-Bliesner, B., and Weber, S. L.: A multi-model analysis of the role of the ocean on the African and Indian monsoon during the mid-Holocene, Clim. Dynam., 25, 777-800, doi:10.1007/s00382-005-0075-7, 2005.

Zhou, T. J. and Li, Z. X.: Simulation of the east asian summer monsoon using a variable resolution atmospheric GCM, Clim. Dynam., 19, 167-180, doi:10.1007/s00382-001-0214-8, 2002. 